\title{
An Empirical Study of Perception of the End-User on the Acceptance of Smart Government Service in the UAE
}

\author{
Nasser A. Saif Almuraqab, University of Dubai, UAE \\ Sajjad M. Jasimuddin, Kedge Business School, France \\ (iD) https://orcid.org/0000-0003-2627-9241
}

Wathiq Mansoor, University of Dubai, UAE

\begin{abstract}
Smart government initiative allows citizens to access government services using mobile technologies such as mobile phones. The end-user acceptance of electronic government applications is crucial for the effective delivery of public services. This study investigates the factors that influence the end-user acceptance of smart-government services. By reviewing the existing literature, this paper identifies key determinants of the end-user acceptance of smart government services in the UAE in order to develop a theoretical model which is then tested empirically, using the partial least squares structural equation modelling (PLS-SEM). This study examines the relationship among the factors that influence the adoption of smart government applications, along with the moderation effects of gender, age, and experience of the end-users on this linkage. The paper reveals that performance expectancy is the strongest factor influencing adoption of smart government, followed by trust in government, effort expectancy, and social influence. Utilizing the multi group analysis (MGA) feature, the data was further analyzed to test the moderation effects of the gender, age, and smart service use experience of the end-users on the relationship between the factors that influence smart-government service adoption and intention to smart government services use. The paper helps understand the key determinants surrounding the end-user acceptance of smart government services. Accordingly, policy makers and practitioners can give emphasis on the factors that enhance the adoption of smartgovernment services.
\end{abstract}

\section{KEYWORDS}

Electronic Government Information, Public Services, Smart Government, Technology Adoption, Trust

\section{INTRODUCTION}

The advancement of information and communication technologies (ICT) has led to the development of new applications and services. The fact that Wi-Fi-enabled devices and wireless networks expedite the efficient operation and delivery of public services (Ghyasi \& Kushchu, 2004). The smart technologies such as mobile devices have revolutionised the approach to operations management in industries (Lansiti \& Lakhani, 2014). With smart Government initiative, citizens can get to access government services using mobile internet technologies such as mobile phones. Since such technologies allow frequent interactions between governments and citizens (Al-Thunibat et al., 2011), governments 
around the globe are moving towards smart government using mobile devices to improve the level of connection with citizens, and improve the nature of service arrangement (Abdelghaffar \& Magdy 2012).

Smart Government initiatives have been launched to provide services to citizens by means of the Internet with different level of success (Al-khamayseh et al., 2007; Jasimuddin et al., 2017). The fact that smart systems enable the use and deployment of information to meet the needs of users (Khan et al., 2017). Smart Government refers to the use of the Internet and mobile computing that has the ability to transform relationships with end-users, businesses, and other arms of government (World Bank, 2015). The impact of mobile devices is so wide that the government organisations have undergone a digital business transformation in knowledge society (Islam et al., 2017). Due to this, the interactions between end-users and the public sector, in terms of lifestyles as well as business transactions has been changed.

The number of smartphone users worldwide today surpasses three billion (O'Dea, 2020). Despite the large number of smart-government initiatives which have been launched in many parts of the world, most of these initiatives were met with low rates of acceptance by citizens, especially in developing countries (Al-Thunibat et al., 2011). Policy-makers and scholars face the questions relating to the opportunities and challenges of smart-government services.

There is limited research that focus on the investigation of the successful adoption of smartgovernment services (Almuraqab \& Jasimuddin, 2016). Among developing countries, the Arab world seems to have attracted little attention in terms of the adoption of smart government. Due to the massive smart-technology revolution, the UAE government now is working smarter by providing services over smart devices. The UAE is among the best countries in the world that keeps pace with leading programs in governmental development, service development, and innovation fields (Al Zaabi, 2019). The reality in the UAE is that the performance of the government sector in the delivery of services to end-users is below average (UN e-government development index, 2014). Surprisingly, a large number of the UAE population do not have computers or Internet access. Moreover, Debusmann (2015) reported that $65 \%$ of the respondents under study had never used smart-government applications in the UAE.

The success of smart-government initiatives is a function of citizen engagement (Almuraqab, 2017). Parallel to this, Al-Thunibat et al. (2011) suggest that critical engagement between the government and its citizens is required for the government services success. The understanding of smart government acceptance is crucial because the investment in mobile devices is of little value if it is not accepted and used (Oye et al., 2014). Achieving acceptance of smart technologies in government services by citizens is a challenge (Susanto \& Goodwin 2011). Against this backdrop, the identification of the factors that influence the acceptance of smart government services is an important research area (Wu et al. 2009). The insights of Venkatesh et al.'s (2003) the Unified Theory of Acceptance and Use of Technology (UTAUT) inspired the theoretical foundation of this study. Hence, this article addresses the issues such as enablers of the operations of smart-government services from the endusers' perspective in the UAE context which is a major concern of the policy-makers, practitioners and scholars. The paper will help to understand the key issues surrounding the successful operations of smart-government services.

The remainder of this paper is organised as follows. First, the factors that influence the intention to use smart-government services applications are identified, their relationships are discussed, research hypotheses are developed, and the conceptual framework is presented. The research methodology is then discussed, and the results of the statistical analysis are reported. Following a discussion of the results, we highlight theoretical and practical implications, and finally provide limitations and research suggestions. 


\section{LITERATURE REVIEW AND HYPOTHESES DEVELOPMENT}

This section reviews the literature to propose a research model. A review of the literature shows that academicians and professionals do not consider seriously the challenges faced in adopting smart government (mobile-applications-based) initiative. By reviewing the existing literature (e.g. AlAwadhi \& Morris, 2008; Carter, 2008; Hussein et al. 2011; Liu et al., 2014; Nfuka \& Rusu 2011; Ovais et al., 2013; Rehman et al., 2012; Shareef et al., 2012; Yong et al., 2014; Almuraqab er al., 2017; Abdou \& Jasimuddin, 2020), this paper identifies key determinants of the end-users' acceptance of smartgovernment services in the UAE context so as to develop a theoretical model which is then tested empirically. Table 1 shows the factors that influence the adoption of smart government services.

As mentioned earlier, the insights of Venkatesh et al.'s (2003) UTAUT model inspired the theoretical foundation of this study. In addition, the proposed model incorporates additional variables

Table 1. Summary of previous e- government adoption studies

\begin{tabular}{|c|c|c|}
\hline Author(s) & Region & Adoption factors \\
\hline $\begin{array}{l}\text { Abdelghaffar \& Magdy } \\
\qquad(2012)\end{array}$ & Egypt & Perceived usefulness, compatibility, awareness, and social influence \\
\hline Alomari et al. (2012) & Jordan & $\begin{array}{c}\text { Trust of government, website design, beliefs, complexity and perceived } \\
\text { usefulness. }\end{array}$ \\
\hline Alsaif (2014) & $\begin{array}{c}\text { Saudi } \\
\text { Arabia }\end{array}$ & $\begin{array}{l}\text { Performance expectancy, effort expectancy, social influence, trust of } \\
\text { internet, computer self-efficacy, and availability of resources. }\end{array}$ \\
\hline $\begin{array}{l}\text { Al-Shafi \&Weerakkody } \\
\qquad(2010)\end{array}$ & Qatar & $\begin{array}{c}\text { Effort expectancy, peer influence, performance expectancy, and facilitating } \\
\text { condition. }\end{array}$ \\
\hline Carter (2008) & USA & Perceived usefulness, trust of the internet, and perceived ease of use. \\
\hline $\begin{array}{l}\text { Carter \& Weerakkody, } \\
\text { (2008) }\end{array}$ & UK & $\begin{array}{l}\text { Performance expectancy, effort expectancy, social influence, relative } \\
\text { advantages and trust }\end{array}$ \\
\hline Dahi \& Ezziane (2015) & UAE & Perceived usefulness, perceived ease of use, subjective norms, and trust. \\
\hline Hussein et al. (2011) & Indonesia & $\begin{array}{l}\text { Perceived ease of use and perceived usefulness, trust in the government, } \\
\text { image, compatibility and service quality. }\end{array}$ \\
\hline Khalil (2014) & Kuwait & $\begin{array}{l}\text { Effort expectancy, social influence, facilitating condition, trust, and } \\
\text { awareness. }\end{array}$ \\
\hline Kurfalı et al. (2017) & Turkey & $\begin{array}{l}\text { Performance expectancy, Effort expectancy, Social influence, Facilitating } \\
\text { conditions and Trust of Internet }\end{array}$ \\
\hline Liu et al. (2014) & China & $\begin{array}{l}\text { Perceived ease of use, near-term usefulness, long-term usefulness, integrity, } \\
\text { benevolence, image and social influence }\end{array}$ \\
\hline Rehman et al. (2012) & Pakistan & $\begin{array}{l}\text { Information quality, awareness, perceived ease of use, service quality and } \\
\text { transaction security. }\end{array}$ \\
\hline $\begin{array}{l}\text { Sabraz \& Thelijjagoda } \\
\text { (2015) }\end{array}$ & Sri Lanka & Performance expectancy, effort expectancy, and social influence \\
\hline Shareef et al. (2012) & India & $\begin{array}{l}\text { Perceived ease of use, perceived security, perceived reliability, and relative } \\
\text { advantage }\end{array}$ \\
\hline Sang et al. (2010) & Cambodia & Perceived usefulness, relative advantage, trust, and perceived ease of use. \\
\hline Suki \& Ramaya (2010) & Malaysia & $\begin{array}{c}\text { Perceived usefulness, perceived ease of use, attitude, facilitating conditions, } \\
\text { self-efficacy, subjective norms, perceived behavioral control, interpersonal } \\
\text { influence, and external influence }\end{array}$ \\
\hline Tarhini et al. (2016) & Lebanon & $\begin{array}{l}\text { performance expectancy, Effort expectancy, Social influence, Facilitating } \\
\text { conditions social influence, perceived credibility, task-technology fit }\end{array}$ \\
\hline
\end{tabular}


trust in technology (TiN) and trust in government (TiG). Figure 1 depicts the conceptual model that guides the execution of the study, offering an empirical test for several hypotheses regarding these concepts, which are developed in the following paragraphs.

Performance Expectancy (PE). This term refers to the degree to which individuals believe that using a system helps improve their job performance (Venkatesh et al., 2003). PE will be measured by examining the perception that the use of smart-government services helps to save time, money, and effort, and improve the quality of government services. In fact, many researchers (e.g., Sabraz \& Thelijjagoda, 2015; Alshehri et al., 2013; AlAwadhi \& Morris, 2008; Al-Shafi \& Weerakkody, 2010) have asserted that PE is a significant factor influencing users' adoption of smart-government services. Contrarily, Khalil (2014) argues that PE is an insignificant factor in users' intention to use the e-payment system in Kuwait to pay the fine for a traffic violation. Moreover, Khalil (2014) reveals that citizens believe that transacting with government agencies and its systems is generally timeconsuming, inconvenient and boring. However, people begin to use the newly offered government system and change their traditional ways once they learn. Such a system is timesaving, cost effective, more convenient, more efficient, and accessible anywhere at any time (Shareef et al., 2012). It is argued that the behavioral intention of the end-users to adopt smart-government services is affected significantly by performance expectancy of the end-users.

Moreover, performance expectancy will be more significant towards behaviour intention to adopt smart-government services if it is moderated by demographic variables (such as gender, age, and technology experience). For example, performance expectancy is significant for young people's intention to use m-government services. Similarly, male may have more positive attitudes towards using technology compared to female users. It can be claimed that the adoption of e-government services is dependent on technology experience. Hence, gender (female and male), age (older and youth) and mobile internet use experience (more and less experienced) of the end-users have moderating effect on the relationship between social influence and intention to adopt smart government services use.

Similarly, male may have more positive attitudes towards using technology compared to female users. Scholars (e.g., Morris and Venkatesh, 2000; Venkatesh et al., 2000) examined the role of gender in the adoption and usage of technology, highlighting gender as one of the most important variables when adopting technology. For example, Venkatesh et al., (2000) showed that male users use a technology more than females. Similarly, several authors (Gilbert et al., 2004; Venkatesh et al., 2003; Morris and Venkatesh, 2000) contend that age significantly moderates the influence of the determinants on behaviour intention. Gilbert et al. (2004) found that the effect of perceived usefulness on behaviour intention was moderated by age. Moreover, previous studies (e.g., Trocchia and Janda, 2000) have revealed that research on technology experience has an important effect when considering technology adoption and usage in organisational context. Trocchia and Janda's (2000) research on age differences indicates that the younger age groups tend to be more willing to adopt computer usage than the older age groups

Hence, it can be claimed that performance expectancy is significant for young people's intention to use m-government services. Similarly, the adoption of e-government services is dependent on technology experience. In other words, gender (female and male), age (older and youth) and mobile internet use experience (more and less experienced) of the end-users have moderating effect on the relationship between social influence and intention to adopt smart government services use. Based on this discussion, the following hypotheses are posited.

$\mathrm{H} 1$ : Behavioral intention to adopt smart-government services is affected significantly by performance expectancy $(\mathrm{PE})$.

H1a: Gender moderates the relationship between PE and the intention to use smart government.

H1b: Age moderates the relationship between PE and the intention to use smart government.

H1c: Mobile internet experience moderates the relationship between PE and the intention to use smart government. 


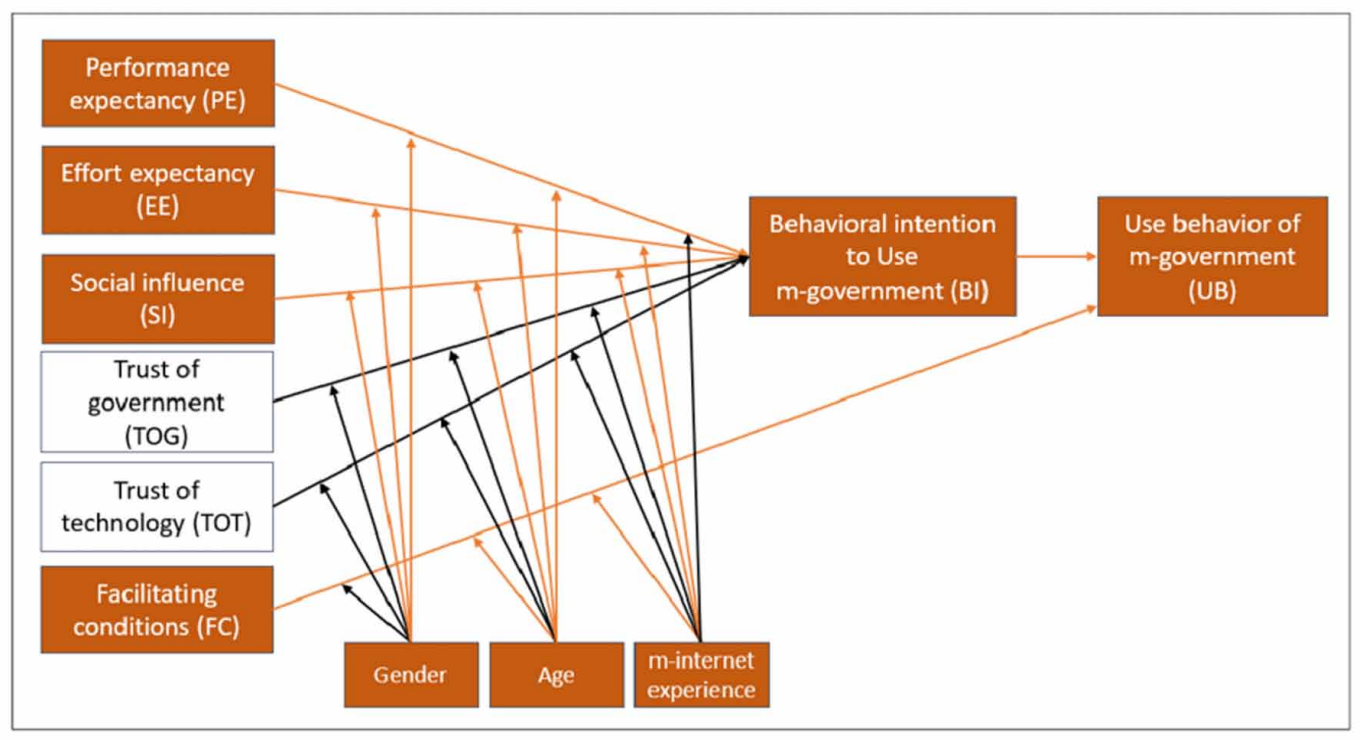

Effort Expectancy (EE). This term refers to the degree of ease associated with the use of a system (Venkatesh et al., 2003). EE can be measured by the perception of the ease of use of smartgovernment services, as well as the ease of learning how to use them. The fact that ease of use is a critical factor influencing end-users' adoption behavior in the context of UAE. However, the EE variable is incorporated with the complexity variable from diffusion of innovation (DOI) and the perceived ease of use. In this regard, researchers (e.g., Sabraz \& Thelijjagoda, 2015; AlAwadhi \& Morris, 2008; Al-Shafi \& Weerakkody, 2010) have shown that EE is a critical factor influencing end-users in their acceptance of smart-government systems. It is argued that the behavioral intention of the end-users to adopt smart-government services is affected significantly by effort expectancy of the end-users.

Effort expectancy of the end-users will be more significant towards behaviour intention to adopt smart-government services if it is moderated by demographic variables such as gender, age, gender and technology experience. Moreover, gender (female and male), age (older and youth) and mobile internet use experience (more and less experienced) of the end-users have moderating effect on the relationship between effort expectancy and intention to adopt smart government services use. Hence, the following hypotheses are suggested.

$\mathrm{H} 2$ : Behavioral intention to adopt smart-government services is affected significantly by effort expectancy (EE).

$\mathrm{H} 2 \mathrm{a}$ : Gender moderates the relationship between EE and the intention to use smart government. $\mathrm{H} 2 \mathrm{~b}$ : Age moderates the relationship between EE and the intention to use smart government. $\mathrm{H} 2 \mathrm{c}$ : M-internet moderates the relationship between $\mathrm{EE}$ and the intention to use smart government.

Social Influence (SI). This term denotes the degree to which peers influence the use of the system, whether positively or negatively (Venkatesh et al., 2003). SI is a primary factor in many aspects of peoples' lives and is likely to be a significant factor. This construct will be measured by examining the perception of how others affect the use of smart-government services. Al Thunibat and Sahari (2011) argue that SI is a critical factor affecting users' intention to utilize smart government 
services. Conversely, there are studies in this field where SI is found as an insignificant predictor of the acceptance of smart-government services (George, 2002; Hussein et al., 2011; Alomari et al., 2012). Scholars (e.g., Sabraz \& Thelijjagoda, 2015; Liu et al., 2014; Khalil, 2014) have tested and proved that social influence of the end-users has a significant impact in adopting smart-government services.

It is argued that the behavioral intention of the end-users to adopt smart-government services is affected significantly by social influence of the end-users. Abdelghaffar and Magdy (2012), for example, found that social influence is significant for young people's intention to use m-government services. Most specifically, gender (female and male), age (older and youth) and mobile internet use experience (more and less experienced) of the end-users have moderating effect on the relationship between social influence and intention to adopt smart government services use. Based on this discussion, the following hypotheses are developed.

H3: Behavioral intention to adopt smart-government services is affected significantly by social influence (SI).

H3a: Gender moderates the relationship between SI and the intention to use smart government.

H3b: Age moderates the relationship between SI and the intention to use smart government.

H3c: Mobile internet moderates the relationship between SI and the intention to use smart government.

Facilitating Conditions (FC). Facilitating conditions (FC) refers to the availability of organizational and technological resources that supports the use of smart-government services and the degree of compatibility with the end user (Venkatesh et al., 2003). It is anticipated that this factor would be important for the adoption of smart-government services. This construct was measured by weighing the end user's perception of accessing the resources, knowledge, and technical support needed to use smart-government services systems, and assessing the compatibility of these services with the end user's life and work styles. The availability of facilitating conditions can be understood as the ease with which one can access necessary resources and obtain the knowledge required to use e-government services (AlAwadhi \& Morris, 2008). For example, Dahi and Ezziane (2015) reported that some users claim a lack of resources hamper their use of smart government systems. Several researchers (e.g., AlAwadhi \& Morris, 2008; Suki \& Ramayah, 2010) reveal in their study that the facilitating conditions have a significant impact on smart-government adoption.

It is argued that the behavioral intention of the end-users to adopt smart-government services is affected significantly by facilitating conditions of the end-users. It can be claimed that the adoption of smart-government services is dependent on age, gender, and technology experience. Therefore, gender (female and male), age (older and youth) and mobile internet use experience (more and less experienced) of the end-users have moderating effect on the relationship between facilitating condition and intention to adopt smart government services use. Based on this discussion, the following hypotheses are proposed.

H4: Use behavior with respect to smart-government services is affected significantly by facilitating conditions (FC).

H4a: Gender moderates the relationship between FC and the use of smart government.

H4b: Age moderates the relationship between FC and the use of smart government.

H4c: M-internet moderates the relationship between FC on the use of smart government.

Trust in Technology (TiT). This term means the degree of users' trust in the Internet and technologies that are used to access smart -government. Trust is repeatedly mentioned as a key factor of digitally-based service adoption (Pavlou, 2003). Carter \& Bélanger (2005) stated that end-users must have confidence in the enabling technologies. The concept of TiT has been widely debated and has been proved relevant in smart-government services (Carter \& Bélanger, 2005; Pavlou, 2003). This 
view of trust has been commonly adopted by researchers in e-government services (Carter, 2008). The UAE currently faces the challenge of establishing an up-to-date legal framework to govern the ICT utilization. This involves issues such as consumer protection, cybercrime, and data privacy (AlKhouri, 2012). Accordingly, Internet users may be concerned about the privacy and security of their information, even when dealing with government agencies through smart devices.

It is argued that the behavioral intention of the end-users to adopt smart-government services is affected significantly by trust of the end-users in technology. It can be claimed that the adoption of smart-government services is dependent on age, gender, and technology experience. Therefore, gender (female and male), age (older and youth) and mobile internet use experience (more and less experienced) of the end-users have moderating effect on the relationship between trust of the endusers in technology and intention to adopt smart government services use. Based on these arguments, discussion, the following hypotheses are suggested.

H5: Behavioral intention to adopt smart-government services is affected significantly by trust of technology (TiT).

H5a: Gender moderates the relationship between TiT and the intention to use smart government.

H5b: Age moderates the relationship between TiT and the intention to use smart government.

H5c: Mobile-internet moderates the relationship between TiT and the intention to use smart government.

Trust in Government (TiG). This term indicates the degree of residents' trust in governmentbased services and their perceptions of government departments' integrity and their ability to provide smart government services according to the residents' expectations (Carter \& Bélanger, 2005). According to Al Thunibat and Sahari (2011), government surrounds people who live in a city and infringes upon their personal lives on almost a daily basis. Similarly, Carter and Bélanger (2005) emphasize that residents of a city must have confidence in the government. Furthermore, Rehman et al. (2012) state that the lack of trust in government is one of the major factors that leads to the failure of e-government projects.

Trust in government was proposed as a significant impact on smart-government adoption. Trust in government organizations or agencies refers to the belief in the capability of the departments and the staff to implement online services through smartphone apps. The hypothesis predicts that end-user trust in government departments or agencies will significantly affect their intention to use smartgovernment services. These researchers reported a direct significant impact of trust in government on the intention to use electronic government services. Furthermore, a study by Abu-Shanab (2014) highlighted the importance of trust in government in e-government adoption.

These findings showed that trust in government is an important factor influencing the intention to use smart-government services, particularly when users are required to provide their confidential personal information, such as Emirates ID, credit card, bank account, or contact details. Indeed, the end-users view government as Big Brother (Al Thunibat \& Sahari, 2011). In fact, users need to believe that government agencies provide smart-government services for the purpose of benefitting, and not monitoring and policing them (Al Thunibat \& Sahari, 2011). Several studies have used this factor to explain end-users' intentions to use e-government services (e.g., Alomari et al., 2012; Dahi \& Ezziane, 2015). For example, Alomari et al. (2012) highlight the lack of collaboration between the government of Jordan and its entities in terms of laws and regulations.

It is argued that the behavioral intention of the end-users to adopt smart-government services is affected significantly by trust of the end-users in government. It can be claimed that the adoption of smart-government services is dependent on age, gender, and technology experience. Therefore, gender (female and male), age (older and youth) and mobile internet use experience (more and less experienced) of the end-users have moderating effect on the relationship between trust of the end- 
users in government and intention to adopt smart government services use. Based on these arguments, discussion, the following hypotheses are suggested.

H6: Behavioral intention to adopt smart-government services is affected significantly by trust in government $(\mathrm{TiG})$.

H6a: Gender moderates the relationship between TiG and the intention to use smart government. H6b: Age moderates the relationship between and the intention to use smart government. H6c: M-internet moderates the relationship between TiG and the intention to use smart government.

Behavioral Intention (BI) to use. Behavioural intention refers to a c customer's/intention to ladopt

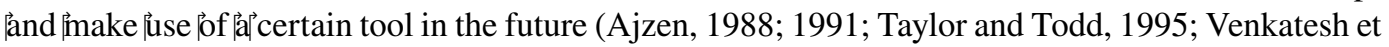
al., 2003; Irani et al., 2009). Venkatesh et al. (2003) defined|behavioral intention äs’an ¡individual's perception that she/he will possibly perform the behavior in question. The majority of technology (e.g., e-government applications services) adoption research has utilized behavioural intention to predict technology adoption. The fact that behavioural intention has a strong positive influence on use behavior (Ajzen, 1991). Behavioural intention will be measured by the intended, predicted, and planned use of smart-government services. Venkatesh et al. (2003) strongly argue that behavioural intention has a strong positive influence on use behavior. Several scholars (e.g., Al-Shafi and Weerakkody, 2010; Hennington and Janz, 2007; Venkatesh et al., 2003) have confirmed the relationship between behavioural intention and behavioural use of e-government services. That is, behavioural intention plays significant role in explaining the behaviour of usage and adoption of smart government services aplicaitons. Hence, the following hypothesis is suggested.

H7: Behavioral intention (BI) to adopt smart-government services significantly influences usage behavior (UB).

\section{RESEARCH METHODOLOGY}

The partial least squares structural equation modelling (PLS-SEM) is widely used in information systems, strategic management, marketing research and beyond (Hair et al., 2012; Henseler et al., 2016), which is capable to examine the complex research model and hypotheses collectively. This study employs PLS-SEM approach to the path coefficients, i.e., direct and indirect effects between latent variables, and determine the predictive power of the model. Most specifically, this approach will offer an analysis of the relationships between the constructs (e.g., performance expectancy, effort expectancy, social influence, facilitating condition, trust in technology, trust in government, behavioural intention to adopt smart-government, and behavioural use of smart-government applications).

\section{Instruments}

\section{Sample}

With the introduction of Smart Government initiative, citizens will be able to access smart-government services. A multi-industry sampling design was used to broaden the generalisability of the findings (Katsikea et al. 2011). The questionnaire used a five-point Likert-type scale to measure responses. The questionnaires with a cover letter explaining the research objective were distributed. A self-addressed postage-paid envelope were included in the package. Initially, the questionnaire was piloted using 20 respondents to increase the clarity of the questions and to avoid interpretation errors. Moreover, it was translated and back-translated to ensure that the Arabic translation accurately reflected the meaning of the English version and to reduce comprehension problems (Sperber et al., 1994). A 
reliability check utilizing SmartPLS3 was conducted using Cronbach's alpha reliability coefficient, which ensures the consistency of the constructs. A preliminary regression analysis was conducted to remove outliers that exceeded limits on specific measures or were extremely odd. The final sample size for analysis was 273 , which satisfies the generalizability conditions and the adequacy of analysis.

\section{Measurements}

A rigorous review of the extant literature was undertaken to develop the observed items of all the latent variables in order to address the relationship between constructs (performance expectancy, effort expectancy, social influence, trust in government, trust in technology, facilitating conditions, behavioural intention to adopt smart-government, and behavioural use of smart-government applications) and the moderating effect of gender, age, experience on this linkage. Measurement of the research constructs involved the employment of multi-item reflective scales (Bollen \& Lennox, 1991), which enhances confidence so that the measurement of the research construct will be consistent (Churchill, 1979).

Performance expectancy was measured with items adopted from the work of Sabraz and Thelijjagoda, 2015; Alshehri et al., 2013; AlAwadhi and Morris, 2008; Al-Shafi and Weerakkody, 2010). The respondents rated the items on a Likert scale of 1 (strong disagreement) to 5 (strong agreement). The composite reliability of the measures is 0.94 , which are derived using partial least squares structural equation modelling (PLS-SEM) approach (as shown in Table 4).

To measure effort expectancy, we used four items adopted from Sabraz \& Thelijjagoda, 2015; Khalil, 2014). The respondents rated the items on a Likert scale of 1 (strong disagreement) to 5 (strong agreement). The composite reliability of the measures is 0.93 .

Social influence was measured on a scale that was developed using the related literature (e.g., Liu et al., 2014). The composite reliability of the measures is 0.95 .

Facilitating condition was measured on a scale that was developed using the related literature (e.g., Dahi \& Ezziane, 2015; AlAwadhi \& Morris, 2008). The scale of the measures (composite reliability $=0.92$ ) consisted of six items.

Trust in technology was assessed using a five-item scale, drawn from the relevant literature (e.g., Carter \& Bélanger, 2005; Carter, 2008; Alomari et al., 2012). The composite reliability of the measure is 0.90 .

Trust in government was measured on a scale that was developed using the related literature (e.g., Rehman et al., 2012; Al Thunibat \& Sahari, 2011; Dahi \& Ezziane, 2015). The scale of the measures (composite reliability $=0.91$ ) consisted of three items.

Behavioral intention was assessed using a three-item scale, drawn from the relevant literature (e.g., Venkatesh et al., 2003). The composite reliability of the measures is 0.93.

\section{RESULTS ANALYSIS}

Data were analysed and interpreted based on Structural Equation Modelling (SEM) using Partial Least Square (SmartPLS v3). The analysis was designed as a structure equation model using survey data on 273 end-users, covering information on various measures on performance expectancy, effort expectancy, social influence, trust in government, trust in technology, facilitating conditions and Behavioral intention to use. Table 2 provides a profile of the respondents in the survey. Most respondents were university-educated (78\%), female (55\%), belong to $31-45$ age group (56\%), and have more than 5 years of experience of using mobile/Internet.

The measurement and structural models are concurrently evaluated to run factor analysis and hypothesis testing (Gefen et al., 2000). Firstly, Confirmatory Factor Analysis (CFA) was undertaken to assess the convergent and discriminant validity. The testing of the research hypotheses then followed to determine the significance of the paths among the constructs. This procedure helps to 
Table 2. Research sample demographic information

\begin{tabular}{|c|c|c|}
\hline Description & Frequency & Percent \\
\hline Gender & 123 & $55 \%$ \\
Male & 150 & $32 \%$ \\
Female & & $56 \%$ \\
Age & 88 & $11 \%$ \\
$(17-30$ (Age1) & 154 & $1 \%$ \\
$31-45$ (Age2) & 29 & $12 \%$ \\
$46-60$ (Age3) & 2 & $10 \%$ \\
Older than 60 (Age4) & & $46 \%$ \\
Education & $34 \%$ \\
High school or less & 28 & $32 \%$ \\
Diploma & 125 & 96 \\
Bachelor's & & $22 \%$ \\
Master's or PhD & & $22 \%$ \\
\hline Mobile internet experience & 26 & $46 \%$ \\
Less than one year & 60 & \\
1-3 years & 61 & \\
3-5 years & & \\
\hline More than 5 years & & \\
\hline
\end{tabular}

understand whether the construct measures are valid and reliable before drawing any conclusion on the relationships among them (Kiessling et al., 2009; Jasimuddin et al. 2019).

Table 3 represents the means, standard deviations, and measurement loadings of all items used for the eight variables. Each of the measurement items should significantly load on its latent construct (Gefen et al., 2000). Our factor loadings ranged from 0.72 to 0.93 , all of which exceed the cut-off value of 0.5 , recommended by Straub (1989).

Convergent validity was supported after examining Cronbach's alpha, composite reliabilities, and average variance extracted (AVE). The internal reliability of the measurement model can be tested using Cronbach's alpha (Fornell \& Larcker, 1981). The Cronbach alpha should be greater than 0.7 to indicate a strong reliability for a questionnaire content (Cuieford, 1965; Nunnally, 1978). In this study, the Cronbach's alpha of each construct was greater than 0.7 . The smallest at 0.81 indicates a strong reliability for our questionnaire content.

Table 4 shows that all the items were correlated significantly to their respective constructs in the measurement model. Composite reliability values should be 0.6 as a cut-off value (Bagozzi \& Yi, 1988). In our study, all composite reliability values exceeded the recommended threshold value, ranging from 0.89 (Use behaviour of smart government services) to 0.95 (social influence), demonstrating composite reliability. AVE values should be greater than 0.5 to validate convergent validity (Hair et al., 2006). As shown in Table 4, all AVE exceeded the recommended threshold value of 0.5, ranging from 0.64 (trust in technology) to 0.86 (social influence), again demonstrating convergent validity.

To assess discriminant validity, Fornell and Larcker (1981) state that the square root of AVE needs to be higher for that construct than its correlation with other constructs. Discriminant validity is confirmed for all the variables as the square root of each variable's AVE are greater than the bivariate correlation. Table 5 shows the inter-construct correlation matrix and the square root of AVE depicted in bold.

\section{Hypothesis Testing}

We next tested the direct relationships, using statistical software SmartPLS 3 version. The procedure allows us to investigate the relationship between key factors that influence the acceptance of smart 
Table 3. Items, Means, Min/Max, and factor loadings

\begin{tabular}{|c|c|c|c|c|c|c|c|c|c|c|}
\hline & & & \multicolumn{8}{|c|}{ Measurement loadings } \\
\hline Item & Mean & Min/Max & PE & EE & SI & FC & TOT & TOG & BI & UB \\
\hline PE1 & 4.223 & $1 / 5$ & 0.88 & & & & & & & \\
\hline PE2 & 4.297 & $1 / 5$ & 0.92 & & & & & & & \\
\hline PE3 & 4.377 & $1 / 5$ & 0.90 & & & & & & & \\
\hline PE4 & 4.322 & $1 / 5$ & 0.84 & & & & & & & \\
\hline EE1 & 4.077 & $1 / 5$ & & 0.88 & & & & & & \\
\hline EE2 & 4.026 & $1 / 5$ & & 0.91 & & & & & & \\
\hline EE3 & 3.993 & $1 / 5$ & & 0.89 & & & & & & \\
\hline EE4 & 4.121 & $1 / 5$ & & 0.87 & & & & & & \\
\hline SI1 & 3.883 & $1 / 5$ & & & 0.93 & & & & & \\
\hline SI2 & 3.864 & $1 / 5$ & & & 0.93 & & & & & \\
\hline SI3 & 3.985 & $1 / 5$ & & & 0.93 & & & & & \\
\hline FC1 & 4.363 & $1 / 5$ & & & & 0.81 & & & & \\
\hline FC2 & 4.223 & $1 / 5$ & & & & 0.77 & & & & \\
\hline FC3 & 3.930 & $1 / 5$ & & & & 0.72 & & & & \\
\hline FC4 & 4.234 & $1 / 5$ & & & & 0.87 & & & & \\
\hline FC5 & 4.051 & $1 / 5$ & & & & 0.83 & & & & \\
\hline FC6 & 4.077 & $1 / 5$ & & & & 0.85 & & & & \\
\hline TOT1 & 3.333 & $1 / 5$ & & & & & 0.78 & & & \\
\hline TOT2 & 3.407 & $1 / 5$ & & & & & 0.83 & & & \\
\hline TOT3 & 3.190 & $1 / 5$ & & & & & 0.74 & & & \\
\hline TOT4 & 3.703 & $1 / 5$ & & & & & 0.83 & & & \\
\hline TOT5 & 3.901 & $1 / 5$ & & & & & 0.80 & & & \\
\hline TOG1 & 4.000 & $1 / 5$ & & & & & & 0.90 & & \\
\hline TOG2 & 4.048 & $1 / 5$ & & & & & & 0.87 & & \\
\hline TOG3 & 3.996 & $1 / 5$ & & & & & & 0.85 & & \\
\hline BI1 & 4.249 & $1 / 5$ & & & & & & & 0.92 & \\
\hline BI2 & 4.216 & $1 / 5$ & & & & & & & 0.89 & \\
\hline BI3 & 4.260 & $1 / 5$ & & & & & & & 0.89 & \\
\hline UB1 & 4.103 & $1 / 5$ & & & & & & & & 0.91 \\
\hline UB2 & 4.051 & $1 / 5$ & & & & & & & & 0.85 \\
\hline UB3 & 3.923 & $1 / 5$ & & & & & & & & 0.79 \\
\hline
\end{tabular}

government services. Table 6 summarises the parameter estimates, significance levels and hypotheses test results.

Hypothesis 1 predicts that performance expectancy has a significant impact on the end-users' intention to use smart-government services. The standardised coefficients of performance expectancy 
Table 4. Constructs reliability

\begin{tabular}{|c|c|c|c|c|c|c|c|c|}
\hline & PE & EE & SI & FC & TiT & TiG & BI & UB \\
\hline Cronbach's alpha & 0.91 & 0.91 & 0.92 & 0.89 & 0.86 & 0.85 & 0.88 & 0.81 \\
\hline $\begin{array}{c}\text { Composite reliability } \\
\begin{array}{c}\text { Average Variance Extracted } \\
\text { (AVE) }\end{array}\end{array}$ & 0.94 & 0.93 & 0.95 & 0.92 & 0.90 & 0.91 & 0.93 & 0.89 \\
\hline
\end{tabular}

and the end-users' intention to use smart-government services are 0.27 , and the $t$-value is $2.94, p<$ 0.000 , indicating statistical insignificance. Thus, Hypothesis 1 is fully supported.

Hypothesis 2 proposes that effort expectancy has a significant impact on the end-users' intention to use smart-government services. The standardised coefficients of effort expectancy on the end-users and the end-users' intention to use smart-government services are 0.17 , and the $t$-value is $1.78, p<$ 0.07, indicating statistical significance. Thus, Hypothesis 2 is supported.

Hypothesis 3 suggests that there is a significant positive relationship between social influence and the end-users' intention to use smart-government services. The standardised coefficients of social influence and the end-users' intention to use smart-government services are 0.14 , and the $t$-value is $1.90, p<0.06$, indicating statistical significance. Thus, Hypothesis 3 is fully supported.

Hypothesis 4 predicts that facilitating conditions has positive influence on the end-users' behavioral use of smart-government services. That is, there is significant positive relationship between facilitating conditions and the end-users' behavioural use smart-government services. Interestingly, the result gives contradictory picture. The standardised coefficients of facilitating conditions and the end-users' behavioural use smart-government services are 0.26 , and the $t$-value is $3.64, p<0.00$, which is statistically significant. Thus, Hypothesis 4 is supported.

Hypothesis 5 proposes that there is a positive relationship between trust in technology and the end-users' intention to smart-government services use. The standardised coefficients of trust in technology and the end-users' intention to use smart-government services are 0.07 , and the $t$-value is $0.98, p<0.31$, indicating statistical insignificance. Thus, Hypothesis 5 is not supported.

Hypothesis 6 predicts that trust in government has a significant impact on the end-users' intention to use smart-government services. The standardised coefficients of trust in government and the endusers' intention to use smart-government services are 0.25 , and the $t$-value is $3.65, p<0.00$, indicating statistical significance. Thus, Hypothesis 6 is supported.

Hypothesis 7 suggests that there is a positive relationship between Behavioral intention to use and the use behavior of smart-government services. The standardised coefficients of Behavioral intention

Table 5. Discriminant validity

\begin{tabular}{|c|c|c|c|c|c|c|c|c|}
\hline & BI & EE & FC & PE & SI & TOG & TOT & UB \\
\hline BI & $\mathbf{0 . 8 9 9}$ & & & & & & & \\
\hline EE & 0.594 & $\mathbf{0 . 8 8 7}$ & & & & & & \\
\hline FC & 0.598 & 0.65 & $\mathbf{0 . 8 0 9}$ & & & & & \\
\hline PE & 0.604 & 0.636 & 0.67 & $\mathbf{0 . 8 8 7}$ & & & & \\
\hline SI & 0.562 & 0.6 & 0.606 & 0.613 & $\mathbf{0 . 9 2 6}$ & & & \\
\hline TOG & 0.58 & 0.554 & 0.498 & 0.458 & 0.498 & $\mathbf{0 . 8 7 4}$ & & \\
\hline TOT & 0.479 & 0.451 & 0.474 & 0.422 & 0.468 & 0.623 & $\mathbf{0 . 7 9 7}$ & \\
\hline UB & 0.688 & 0.623 & 0.575 & 0.484 & 0.489 & 0.463 & 0.486 & $\mathbf{0 . 8 5}$ \\
\hline
\end{tabular}


Table 6. T-Values and $p$-values with general hypothesis status - supported at * $p \leq 0.1$

\begin{tabular}{|c|c|c|c|c|}
\hline Hypotheses & $\boldsymbol{\beta}$ & t-value & p-value & Status \\
\hline $\begin{array}{c}\text { H1:Performance expectancy } \rightarrow \text { behavioral intention to use } \\
\text { smart government services. }\end{array}$ & 0.27 & 2.94 & $0.00 *$ & Supported \\
\hline $\begin{array}{c}\text { H2: Effort expectancy } \rightarrow \text { behavioral intention to use smart } \\
\text { government services. }\end{array}$ & 0.17 & 1.78 & $0.07 *$ & Supported \\
\hline $\begin{array}{c}\text { H3: Social influence } \rightarrow \text { behavioral intention to use smart } \\
\text { government services. }\end{array}$ & 0.14 & 1.90 & $0.06^{*}$ & Supported \\
\hline $\begin{array}{c}\text { H4: Facilitating conditions } \rightarrow \text { behavioral use smart } \\
\text { government services. }\end{array}$ & 0.26 & 3.64 & $0.00 *$ & Supported \\
\hline $\begin{array}{c}\text { H5: Trust of technology } \rightarrow \text { behavioral intention to use smart } \\
\text { government services. }\end{array}$ & 0.07 & 0.98 & 0.31 & $\begin{array}{c}\text { Not } \\
\text { supported }\end{array}$ \\
\hline $\begin{array}{c}\text { H6: Trust of government } \rightarrow \text { behavioral intention to use smart } \\
\text { government services }\end{array}$ & 0.25 & 3.65 & $0.00 *$ & Supported \\
\hline $\begin{array}{c}\text { H7: Behavioral intention to use } \rightarrow \text { use behavior of smart } \\
\text { government services }\end{array}$ & 0.54 & 8.37 & $0.00^{*}$ & Supported \\
\hline
\end{tabular}

to use and the use behavior of smart government services are 0.54 , and the $t$-value is $8.37, p<0.00$, indicating statistically significant. The results indicate that there is significant relationship between Behavioral intention to use and the use behavior of smart government services. Thus, Hypothesis 7 is fully supported.

\section{Multigroup Analysis}

The data was further analyzed to test the effects of the gender, age, and smart service use experience of the respondents. To be sure of the best results in analyzing moderating effects, for each moderating variable there are tables showing Cronbach's alpha, AVE, composite reliability, and factor loadings. Tables 7, 8, and 9 are followed by Table 10 containing the results of the $p$ and $t$ tests, as well as the results for the hypotheses utilizing the Multi Group Analysis feature (MGA).

To investigate the moderating effect of the gender of the end-users on the relationship between the factors that influence smart-government service adoption and intention to smart government services use, the sample was divided into two groups, i.e., (1) female and (2) male. Similarly, to investigate the moderating effect of the the end-users' age on the relationship between the factors that influence smart-government service adoption and intention to smart-government services use, the sample was divided into two groups, i.e., (1) youth (age between 17 and 45 years) and (2) older (age above 45 years). Again the sample was divided into two groups, i.e., (1) more experienced and (2) less experienced, to investigate the moderating effect of the end-users' experience on the relationship between the factors that influence smart-government service adoption and intention to smart-government services use. The findings in Table 7 indicate that the two groups, created on the basis of gender, age, and experience were different on three parameters.

\section{DISCUSSION}

This paper sets out to investigate the relationship among constructs (e.g., performance expectancy, effort expectancy, social influence, facilitating condition, trust in technology, trust in government, behavioural intention to adopt smart government applications, and behavioural use of smart government services), along with the moderation effects of gender, age, and experience of the endusers on this linkage. The empirical results derived from this research demand a discussion along 
Table 7. Cronbach's alpha, AVE, composite reliability and factor loadings-Gender groups

\begin{tabular}{|c|c|c|c|c|}
\hline & Item & Complete & Male & Female \\
\hline \multirow[t]{3}{*}{ Performance expectancy } & $A V E$ & 0.91 & 0.78 & 0.79 \\
\hline & Composite reliability & 0.94 & 0.94 & 0.94 \\
\hline & Cronbach's alpha & 0.79 & 0.91 & 0.91 \\
\hline PE1 & & 0.88 & 0.91 & 0.87 \\
\hline PE2 & & 0.92 & 0.92 & 0.92 \\
\hline PE3 & & 0.90 & 0.88 & 0.92 \\
\hline PE4 & & 0.84 & 0.84 & 0.85 \\
\hline \multirow[t]{3}{*}{ Effort expectancy } & $A V E$ & 0.91 & 0.85 & 0.74 \\
\hline & Composite reliability & 0.93 & 0.96 & 0.92 \\
\hline & Cronbach's alpha & 0.79 & 0.94 & 0.88 \\
\hline EE1 & & 0.88 & 0.93 & 0.84 \\
\hline EE2 & & 0.91 & 0.93 & 0.89 \\
\hline EE3 & & 0.89 & 0.92 & 0.87 \\
\hline EE4 & & 0.87 & 0.90 & 0.84 \\
\hline \multirow[t]{3}{*}{ Social influence } & $A V E$ & 0.92 & 0.89 & 0.83 \\
\hline & Composite reliability & 0.95 & 0.96 & 0.94 \\
\hline & Cronbach's alpha & 0.86 & 0.94 & 0.90 \\
\hline SI1 & & 0.93 & 0.94 & 0.91 \\
\hline SI2 & & 0.93 & 0.95 & 0.9 \\
\hline SI3 & & 0.93 & 0.94 & 0.92 \\
\hline \multirow[t]{3}{*}{ Facilitating conditions } & $A V E$ & 0.89 & 0.71 & 0.62 \\
\hline & Composite reliability & 0.92 & 0.94 & 0.91 \\
\hline & Cronbach's alpha & 0.66 & 0.92 & 0.88 \\
\hline FC1 & & 0.81 & 0.83 & 0.81 \\
\hline FC2 & & 0.77 & 0.80 & 0.76 \\
\hline FC3 & & 0.72 & 0.79 & 0.67 \\
\hline FC4 & & 0.87 & 0.89 & 0.84 \\
\hline FC5 & & 0.83 & 0.85 & 0.80 \\
\hline FC6 & & 0.85 & 0.89 & 0.84 \\
\hline \multirow[t]{3}{*}{ Trust of technology } & $A V E$ & 0.86 & 0.66 & 0.61 \\
\hline & Composite reliability & 0.90 & 0.91 & 0.89 \\
\hline & Cronbach's alpha & 0.64 & 0.88 & 0.85 \\
\hline TOT1 & & 0.78 & 0.77 & 0.80 \\
\hline TOT2 & & 0.83 & 0.87 & 0.80 \\
\hline TOT3 & & 0.74 & 0.80 & 0.69 \\
\hline TOT4 & & 0.83 & 0.84 & 0.83 \\
\hline TOT5 & & 0.80 & 0.79 & 0.8 \\
\hline \multirow[t]{3}{*}{ Trust of government } & $A V E$ & 0.85 & 0.79 & 0.75 \\
\hline & Composite reliability & 0.91 & 0.92 & 0.90 \\
\hline & Cronbach's alpha & 0.76 & 0.86 & 0.83 \\
\hline TOG1 & & 0.90 & 0.90 & 0.90 \\
\hline TOG2 & & 0.87 & 0.89 & 0.86 \\
\hline TOG3 & & 0.85 & 0.87 & 0.84 \\
\hline \multirow[t]{3}{*}{ Behavioral intention } & $A V E$ & 0.88 & 0.81 & 0.82 \\
\hline & Composite reliability & 0.93 & 0.93 & 0.93 \\
\hline & Cronbach's alpha & 0.81 & 0.88 & 0.89 \\
\hline BI1 & & 0.92 & 0.92 & 0.92 \\
\hline BI2 & & 0.89 & 0.86 & 0.91 \\
\hline BI3 & & 0.89 & 0.92 & 0.88 \\
\hline \multirow[t]{3}{*}{ Use Behavior } & $A V E$ & 0.81 & 0.79 & 0.68 \\
\hline & Composite reliability & 0.89 & 0.92 & 0.86 \\
\hline & Cronbach's alpha & 0.72 & 0.86 & 0.76 \\
\hline UB1 & & 0.91 & 0.92 & 0.90 \\
\hline UB2 & & 0.85 & 0.89 & 0.83 \\
\hline UB3 & & 0.79 & 0.85 & 0.73 \\
\hline
\end{tabular}


Table 8. Cronbach's alpha, AVE, composite reliability and factor loadings-Age groups

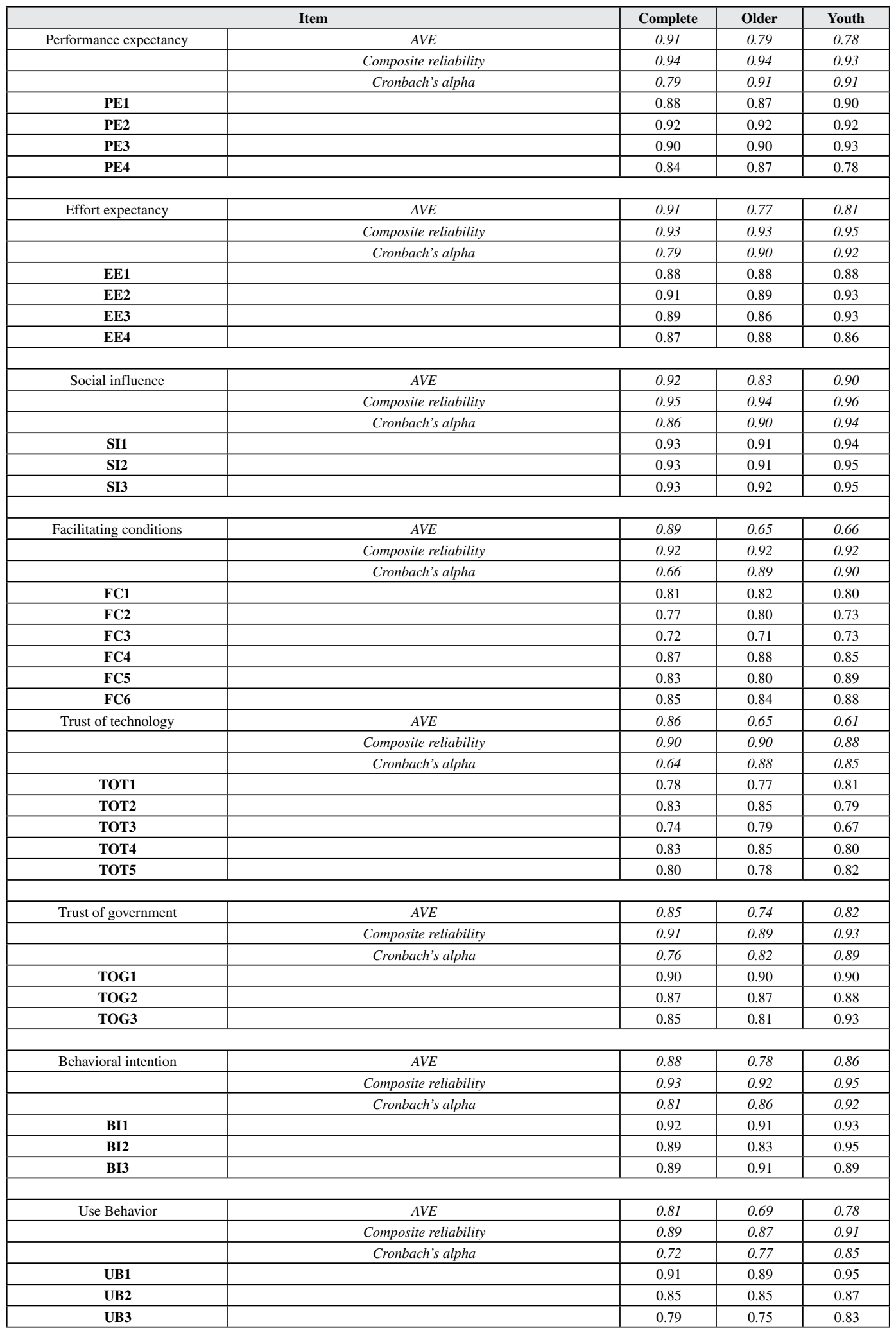


Table 9. Cronbach's alpha, AVE, composite reliability and factor loadings-Experience groups

\begin{tabular}{|c|c|c|c|c|}
\hline \multicolumn{2}{|c|}{ Item } & \multirow{2}{*}{$\begin{array}{c}\text { Complete } \\
0.91\end{array}$} & \multirow{2}{*}{$\begin{array}{c}\text { More Exp. } \\
0.91 \\
\end{array}$} & \multirow{2}{*}{$\begin{array}{c}\text { Less Exp. } \\
0.79\end{array}$} \\
\hline Performance expectancy & $A V E$ & & & \\
\hline & Composite reliability & 0.94 & 0.94 & 0.94 \\
\hline & Cronbach's alpha & 0.79 & 0.91 & 0.91 \\
\hline PE1 & & 0.88 & 0.87 & 0.90 \\
\hline PE2 & & 0.92 & 0.94 & 0.91 \\
\hline PE3 & & 0.90 & 0.89 & 0.92 \\
\hline PE4 & & 0.84 & 0.85 & 0.83 \\
\hline \multirow[t]{3}{*}{ Effort expectancy } & $A V E$ & 0.91 & 0.92 & 0.78 \\
\hline & Composite reliability & 0.93 & 0.94 & 0.93 \\
\hline & Cronbach's alpha & 0.79 & 0.91 & 0.91 \\
\hline EE1 & & 0.88 & 0.89 & 0.87 \\
\hline EE2 & & 0.91 & 0.90 & 0.92 \\
\hline EE3 & & 0.89 & 0.89 & 0.89 \\
\hline EE4 & & 0.87 & 0.87 & 0.86 \\
\hline \multirow[t]{3}{*}{ Social influence } & $A V E$ & 0.92 & 0.94 & 0.87 \\
\hline & Composite reliability & 0.95 & 0.94 & 0.95 \\
\hline & Cronbach's alpha & 0.86 & 0.91 & 0.93 \\
\hline SI1 & & 0.93 & 0.92 & 0.94 \\
\hline SI2 & & 0.93 & 0.90 & 0.95 \\
\hline SI3 & & 0.93 & 0.94 & 0.92 \\
\hline \multirow[t]{3}{*}{ Facilitating conditions } & $A V E$ & 0.89 & 0.90 & 0.64 \\
\hline & Composite reliability & 0.92 & 0.92 & 0.92 \\
\hline & Cronbach's alpha & 0.66 & 0.89 & 0.89 \\
\hline FC1 & & 0.81 & 0.82 & 0.79 \\
\hline FC2 & & 0.77 & 0.78 & 0.75 \\
\hline FC3 & & 0.72 & 0.66 & 0.76 \\
\hline FC4 & & 0.87 & 0.88 & 0.84 \\
\hline FC5 & & 0.83 & 0.84 & 0.82 \\
\hline FC6 & & 0.85 & 0.85 & 0.85 \\
\hline \multirow[t]{3}{*}{ Trust of technology } & $A V E$ & 0.86 & 0.85 & 0.63 \\
\hline & Composite reliability & 0.90 & 0.90 & 0.89 \\
\hline & Cronbach's alpha & 0.64 & 0.87 & 0.86 \\
\hline TOT1 & & 0.78 & 0.81 & 0.77 \\
\hline TOT2 & & 0.83 & 0.83 & 0.82 \\
\hline TOT3 & & 0.74 & 0.71 & 0.77 \\
\hline TOT4 & & 0.83 & 0.81 & 0.85 \\
\hline TOT5 & & 0.80 & 0.84 & 0.75 \\
\hline \multirow[t]{3}{*}{ Trust of government } & $A V E$ & 0.85 & 0.89 & 0.82 \\
\hline & Composite reliability & 0.91 & 0.88 & 0.93 \\
\hline & Cronbach's alpha & 0.76 & 0.79 & 0.89 \\
\hline TOG1 & & 0.90 & 0.86 & 0.93 \\
\hline TOG2 & & 0.87 & 0.82 & 0.92 \\
\hline TOG3 & & 0.85 & 0.84 & 0.87 \\
\hline \multirow[t]{3}{*}{ Behavioral intention } & $A V E$ & 0.88 & 0.92 & 0.82 \\
\hline & Composite reliability & 0.93 & 0.92 & 0.93 \\
\hline & Cronbach's alpha & 0.81 & 0.87 & 0.89 \\
\hline BI1 & & 0.92 & 0.92 & 0.91 \\
\hline BI2 & & 0.89 & 0.90 & 0.88 \\
\hline BI3 & & 0.89 & 0.85 & 0.92 \\
\hline \multirow[t]{3}{*}{ Use Behavior } & $A V E$ & 0.81 & 0.85 & 0.74 \\
\hline & Composite reliability & 0.89 & 0.86 & 0.90 \\
\hline & Cronbach's alpha & 0.72 & 0.76 & 0.83 \\
\hline UB1 & & 0.91 & 0.90 & 0.91 \\
\hline UB2 & & 0.85 & 0.85 & 0.87 \\
\hline UB3 & & 0.79 & 0.72 & 0.81 \\
\hline
\end{tabular}


several lines. This study assessed the proposed model empirically to shed some light on the impact of the key factors on the intention to use smart government services and behavioural use of such services. Table 10 shows this study's hypotheses proposing that gender, age, and experience using online applications moderate the linkage between the key variables and the intention to use smart government.

\section{Performance Expectancy}

The study's findings revealed that the intention to use smart-government services is significantly predicted by the performance expectancy (PE) factor with $\beta=0.27, p \leq 0.1$. This finding aligns with the previous studies (Venkatesh et al., 2003; Sabraz \& Thelijjagoda, 2015) on the adoption of smart-government systems.

Venkatesh et al. (2003) found that men are more influenced than women by benefits that lead to the intention to use information systems. Similarly, in the field of e-government, a study by AlAwadhi and Morris (2008) anticipated that men would tend to be more task-oriented than women. However, the literature did not reflect the gender influence empirically on PE, especially in the UAE. For this reason, it is critical to reveal the impact of gender on PE, especially in the area of smart government. The statistical test of the hypothesis (H1a) showed that women $(\beta=0.28 p \leq 0.1)$ are a bit more influenced by PE than men $(\beta=0.27 p \leq 0.1)$. In both men and women cases, the significance level was the same. This finding is interesting and runs contrary to the findings of Venkatesh et al. (2003). This might be explained by the fact that despite the cultural values and the conservative nature of the UAE society, women are educated, employed, and empowered to the same degree as men. They are dependent upon smart-government mobile apps that enable them to avoid visiting the government offices physically. However, based on the $p$-value of the multigroup analysis (MGA > 0.1 and $<.90$ ), gender is an insignificant moderator of PE on end-users' intentions to use smart-government in the UAE. In other words, the hypothesis is not supported. Also, Alsaif (2014) and Alshehri et al. (2013) report a similar finding on e-government services adoption in Saudi Arabia.

Another hypothesis (H1b) for this research states that age moderates the influence of performance expectancy on intention to use smart-government services. Venkatesh et al. (2003) found that in regard to the adoption of information systems, age moderated the PE to BI relationship (stronger for younger). The statistical results found that age is insignificant moderator. Even though both groups were still significant, the older respondents were found to be slightly more influenced by performance expectancy than the younger respondents in their adoption of smart-government services in the UAE. It is evident that older end-users tend to be more task oriented than younger ones in making government transactions. In addition, younger end-users might depend more on older ones to accomplish other government-related tasks. On the other hand, the MGA test $p$-value was $>0.1$ and $<.90$, which means that the hypothesis is not supported, similar to the study finding reported by Alshehri et al. (2013) in Saudi Arabian e-government adoption.

Furthermore, it was hypothesized that m-internet experience influences performance expectancy and facilitates behavioral intention to use. As for the test methodology above (multigroup analysis), the researchers compared the less experienced group (Exp-L) with the more experienced group (Exp-H), i.e., more than 5 years, to test the hypothesis (H1c). The results of this comparison were that for (Exp-L), $\beta=0.31$ and $\mathrm{p} \leq 0.1$; and for (Exp-H), $\beta=0.24$ and $\mathrm{p} \leq 0.1$. Although for both groups this was significant, a comparison of the values of $\beta$ and $p$ shows that those with less $m$-internet experience were more influenced by performance expectancy than those with greater $m$-internet experience.

However, the multigroup analysis (MGA) revealed an insignificant impact of m-internet experience on PE. Therefore, the hypothesis is not supported $(p>0.1$ and $<.90)$. Although AlAwadhi and Morris (2008) found partial significance of internet experience in using online e-government services, Park et al., (2007) reveal that Internet experience has an insignificant impact on performance 
expectancy in relation to users' intention in China. Khalil (2014) reported similar findings for effects of age, gender, and experience on PE.

\section{Effort Expectancy}

This result indicates that the easier they are to use, the more end users will tend to use m-government systems. The findings of this study are similar to those of Venkatesh et al. (2003). Effect expectancy was revealed to be significant $(\beta=0.17, p \leq 0.1)$. This is supported by AlAwadhi and Morris (2008), Al-Shafi and Weerakkody (2010), and Khalil (2014). However, the study's findings contradict another study done in Egypt by Abdelghaffar and Magdy (2012). As noted earlier, effort expectancy was defined as perceived ease of use. Such findings may be explained by the fact that in the UAE, mobiledevice users are concerned with how easy these applications are to use and whether they required less effort to learn. In other studies of e-government adoption where the end-users care more about the usefulness of these services than the ease of use. Effort expectancy was not found to have a direct effect on intention to use (Carter \& Bélanger, 2004; Al Thunibat \& Sahari, 2011).

Females are more likely to be affected by ease of use $(\beta=.30, p \leq 0.1)$, compared to men $(\beta=$ $0.03, p>0.1)$. As a result, the statistical findings of the multigroup analysis support the hypothesis (H2a) that gender appears to be a critical factor in predicting the influence of effort expectancy on the intention to use smart government in the UAE. This finding is similar to those of Venkatesh et al. (2003) who argue that ease of use of the information system influences women more than men. Alsaif (2014) reported similar findings in Saudi Arabia that women are more influenced toward e-government adoption by ease of use of the system. However, Khalil (2014) reported a contrary finding where males are more influenced by EE compared to females. Alshehri et al. (2013) also reported an insignificant finding of gender impact.

The current research suggests that age will have an influence on effort expectancy (ease of use) and affect end users' intention to use smart government (H2b). Interestingly, the MGA statistical results showed an insignificant impact of age on effort expectancy in its influence on the adoption of smart government in the UAE. Thus, the corresponding hypothesis was not supported. Similar findings reported by Alshehri et al. (2013) in a study of e-government adoption in Saudi Arabia, also by Khalil (2014) in Kuwait. This could perhaps be explained by the fact that ease of use of smart government is not an important predictor of its applications in relation to age. Because smart phones and applications for them have existed for quite a long time, and users in the UAE have become adept and knowledgeable in their use. Furthermore, nowadays even children use smart phones for games. However, contrary to these findings, in a study of behavioral intention in e-banking in Iran by Ghalandari (2012), age was anticipated to be an important factor.

This study also suggests that $\mathrm{m}$-internet experience will moderate the influence of effort expectancy on end-users' intention to accept smart-government services. The statistical analysis showed that EE is an important factor for users with less $\mathrm{m}$-internet experience $(\mathrm{H} 2 \mathrm{c})$. In other words, with more m-internet experience, $\mathrm{EE}$ is not an important factor in predicting smart-government adoption. In information system field, Venkatesh et al. (2003) found that effort expectancy influences BI to a greater degree among less experienced Internet users. Other studies (Al-Gahtani et al., 2007; Alsaif, 2014) of intentional behavior in Saudi Arabia reported that predicting users' behavioral intention based on ease of use (effort expectancy) becomes less important in e-government acceptance when users have more Internet experience. This is supported significantly by the regression findings $(\beta=0.11, p>0.1)$. Contrary to this finding, several other authors (e.g., Alshehri et al., 2013; Khalil, 2014) report that Internet experience positively moderates the influence of effort expectancy. Hence, for those with less experience using the m-internet $(\beta=0.19, p \leq 0.1)$, EE is an important factor in predicting smart-government use. However, the MGA did not show a significant difference between the two groups $(\mathrm{P}>0.1$ and $<0.90)$, which indicates that $\mathrm{m}$-internet experience has insignificant influence on $\mathrm{EE}(\mathrm{H} 2 \mathrm{c})$. 


\section{Social Influence}

Social influence was measured by the perception of how social and public communications affect end-users' intentions to use smart-government services. The results of the analysis showed that a significant impact of social influence (SI) on end-users' behavioral intention. This finding confirms previous literature (Abdelghaffar \& Magdy, 2012; Liu et al., 2014; Sabraz \& Thelijjagoda, 2015). Conversely, there are studies in this field where SI is found as an insignificant predictor of the acceptance of smart-government services (George, 2002; Hussein et al., 2011; Alomari et al., 2012).

This study suggests a moderating effect of gender, age, and m-internet experience on the linkage between social influence and intention to the acceptance of smart government in the UAE. The results of the MGA showed a significant relationship (see Table 10) when the social influence (SI) factor is moderated by gender, significant for men as compared to women. Contrary to this study's findings, Venkatesh et al. (2003) found that in information-system adoption, females are more strongly affected by social influence than males. One explanation of this result could be that in the UAE, men are more task-oriented and more responsible for finalizing government services, compared to women. As a result, they tend to influence each other in order to achieve more government transactions, using their smart phones. Several authors (e.g., Alshehri et al., 2013; Alsaif, 2014; Khalil, 2014) contend that gender was not an important moderating factor on social influence relating to e-government adoption in Saudi Arabia.

The results of the multigroup analysis done for this study showed an insignificant relationship when the social influence (SI) factor was moderated by age and m-internet experience, with $p>0.1$ or $<0.90$. Similarly, Alsaif (2014) contends that in Saudi Arabia, age moderation is insignificant. Conversely, a study by Khalil (2014) revealed that age has insignificant effect on SI. Similarly, Venkatesh et al. (2003) found that in information-system adoption, older users are more influenced by social connections. Moreover, Alshehri et al. (2013) and Ghalandari (2012) reported that age is an important factor influencing the relationship between SI and BI. In addition, Alshehri et al. (2013) and Khalil (2014) reported that Internet experience positively moderates social influence.

\section{Facilitating Conditions}

A facilitating condition means the degree to which an organizational and technical infrastructure exists to support the system (Venkatesh et al., 2003). This variable will be measured by the perception of being able to access resources that support the use of smart-government services. The result reveals that facilitating conditions (FC) have a direct and significant influence on usage behavior (UB) in relation to smart-government services $(\beta=0.26$ and $p<0.1)$. This result supports the direct link between facilitating conditions and usage behavior as revealed by Venkatesh et al. (2003). In the context of the UAE, facilitating conditions include ICT infrastructure within government sectors, accessibility and reliability of government apps, Internet connectivity, technical support, and any other available resources that assist end users and help make these services more compatible with their lifestyles and work schedules, so that they may easily adopt smart-government services. Other empirical research (e.g., AlAwadhi \& Morris, 2008; Khalil, 2014) also supports these results

This study hypothesized that gender, age, and m-internet experience moderate the effect of facilitating conditions on end users' usage behavior in regard to smart-government services. As shown in Table 10, the present study did find that gender has an influence on facilitating conditions, especially for men. Men tend to adopt smart-government services more readily than women. This difference can be seen in the $\beta$ value for men compared to that for women (male group $\beta=0.49$ and $\mathrm{p}<0.1$, female $\beta=0.11$ and $p<0.1$ ). The multigroup analysis statistics also showed a significant difference between the two groups $(p<0.1)$. It was stated earlier that gender segregation in the UAE fosters facilitating conditions (along with compatibility) that promotes the use of smart-government services. It helps to perform government transactions from home which seems to be more compatible with the female lifestyle in the UAE. However, the results show that the men were more influenced by facilitating conditions. This may indicate that women in the UAE believe that government transactions 
Table 10. T-Values and p-values with hypothesis status

\begin{tabular}{|c|c|c|c|c|c|c|c|c|c|}
\hline \multirow[t]{2}{*}{ Gender Moderation hypotheses } & \multicolumn{2}{|c|}{$\beta$} & \multicolumn{2}{|c|}{ t-value } & \multicolumn{2}{|c|}{ p-value } & \multicolumn{2}{|c|}{ PLS (MGA) } & \multirow[t]{2}{*}{ Status } \\
\hline & $\mathbf{F}$ & $\mathbf{M}$ & $\mathbf{F}$ & M & $\mathbf{F}$ & M & $\beta$ & P Value & \\
\hline $\begin{array}{l}\text { H1a: ender moderates the influence of PE on } \\
\text { the BI. }\end{array}$ & 0.28 & 0.27 & 2.35 & 2.17 & $0.02 *$ & $0.03 *$ & 0.01 & 0.53 & Not supported \\
\hline $\begin{array}{l}\text { H2a: Gender moderates the influence of EE } \\
\text { on the BI. }\end{array}$ & 0.30 & 0.03 & 2.50 & 0.25 & $0.01^{*}$ & 0.80 & 0.27 & $0.93(\mathrm{~s})$ & Supported \\
\hline $\begin{array}{l}\text { H3a: Gender moderates the influence of SI } \\
\text { on the BI. }\end{array}$ & 0.11 & 0.15 & 1.03 & 1.69 & 0.30 & $0.09^{*}$ & 0.04 & 0.39 & Not supported \\
\hline $\begin{array}{l}\text { H4a: Gender moderates the influence of FC } \\
\text { on the BI. }\end{array}$ & 0.11 & 0.49 & 1.24 & 5.88 & 0.21 & $0.00^{*}$ & 0.38 & $0.00(\mathrm{~s})$ & Supported \\
\hline $\begin{array}{l}\text { H5a: Gender moderates the influence of TiT } \\
\text { on the BI. }\end{array}$ & 0.04 & 0.01 & 0.54 & 0.08 & 0.59 & 0.94 & 0.04 & 0.61 & Not supported \\
\hline $\begin{array}{l}\text { H6a: Gender moderates the influence of } \mathrm{TiG} \\
\text { on the BI. }\end{array}$ & 0.15 & 0.41 & 1.81 & 3.50 & $0.07 *$ & $0.00^{*}$ & 0.26 & $0.04(\mathrm{~s})$ & Supported \\
\hline \multicolumn{10}{|c|}{ Age Moderation hypotheses } \\
\hline & $\mathbf{o}$ & $\mathbf{Y}$ & $\mathbf{O}$ & $\mathbf{Y}$ & $\mathbf{o}$ & $\mathbf{Y}$ & $\begin{array}{c}\text { PLS } \\
\text { (MGA) }\end{array}$ & $P$ value & Status \\
\hline $\begin{array}{l}\text { H1b: Age moderates the influence of PE on } \\
\text { the BI. }\end{array}$ & 0.28 & 0.23 & 2.31 & 1.96 & $0.02 *$ & $0.05^{*}$ & 0.05 & 0.38 & Not supported \\
\hline $\begin{array}{l}\text { H2b: Age moderates the influence of EE on } \\
\text { the BI. }\end{array}$ & 0.14 & 0.23 & 1.09 & 1.66 & 0.28 & $0.10^{*}$ & 0.09 & 0.69 & Not supported \\
\hline $\begin{array}{l}\text { H3b: Age moderates the influence of SI on } \\
\text { the BI. }\end{array}$ & 0.12 & 0.16 & 1.32 & 1.42 & 0.19 & 0.16 & 0.04 & 0.61 & Not supported \\
\hline $\begin{array}{l}\text { H4b: Age moderates the influence of FC on } \\
\text { the BI. }\end{array}$ & 0.28 & 0.23 & 3.17 & 1.71 & $0.00^{*}$ & $0.09^{*}$ & 0.06 & 0.37 & Not supported \\
\hline $\begin{array}{l}\text { H5b: Age moderates the influence of TiT on } \\
\text { the BI. }\end{array}$ & 0.07 & 0.11 & 0.81 & 1.18 & 0.42 & 0.24 & 0.04 & 0.61 & Not supported \\
\hline $\begin{array}{l}\text { H6b: Age moderates the influence of TiG on } \\
\text { the BI. }\end{array}$ & 0.23 & 0.24 & 2.56 & 2.00 & $0.01 *$ & $0.05^{*}$ & 0.01 & 0.52 & Not supported \\
\hline \multicolumn{10}{|c|}{ M-internet Experience Moderation hypotheses } \\
\hline & $\mathbf{H}$ & $\mathbf{L}$ & $\mathbf{H}$ & $\mathbf{L}$ & H & $\mathbf{L}$ & $\begin{array}{c}\text { PLS } \\
\text { (MGA) }\end{array}$ & $P$ value & Status \\
\hline $\begin{array}{l}\text { H1c: M-Internet experience moderates the } \\
\text { influence of PE on the BI. }\end{array}$ & 0.24 & 0.31 & 1.61 & 3.15 & 0.10 & $0.00^{*}$ & 0.07 & 0.65 & Not supported \\
\hline $\begin{array}{l}\mathrm{H} 2 \mathrm{c} \text { : M-Internet experience moderates the } \\
\text { influence of } \mathrm{EE} \text { on the BI. }\end{array}$ & 0.11 & 0.19 & 0.74 & 1.76 & 0.46 & $0.07^{*}$ & 0.08 & 0.65 & Not supported \\
\hline $\begin{array}{l}\mathrm{H} 3 \mathrm{c}: \text { M-Internet experience moderates the } \\
\text { influence of SI on the BI. }\end{array}$ & 0.17 & 0.14 & 1.61 & 1.31 & 0.11 & 0.19 & 0.04 & 0.40 & Not supported \\
\hline $\begin{array}{l}\mathrm{H} 4 \mathrm{c} \text { : M-Internet experience moderates the } \\
\text { influence of FC on the BI. }\end{array}$ & 0.21 & 0.28 & 1.71 & 4.18 & $0.09^{*}$ & $0.00^{*}$ & 0.07 & 0.69 & Not supported \\
\hline $\begin{array}{l}\text { H5c: M-Internet experience moderates the } \\
\text { influence of TiT on the BI. }\end{array}$ & -0.11 & 0.17 & 1.09 & 2.09 & 0.28 & $0.04 *$ & 0.28 & $0.98(\mathrm{~s})$ & Supported \\
\hline $\begin{array}{l}\text { H6c: M-Internet experience moderates the } \\
\text { influence of TiG on the BI. }\end{array}$ & 0.46 & 0.12 & 4.61 & 1.30 & $0.00^{*}$ & 0.20 & 0.34 & $0.01(\mathrm{~s})$ & Supported \\
\hline
\end{tabular}

${ }^{*} p \leq 0.1$ and for MGA test(s): $p \leq 0.1$ or $p \geq 0.90$

are men's responsibility, which supports the work of Alsaif (2014) and Khalil (2014) done in Saudi Arabia and Kuwait respectively. On the other hand, contrary findings were reported by Ghalandari (2012) in a study that found females in Iran were more influenced by facilitating conditions than males. In summary, gender is an important factor that moderates the relationship between facilitating conditions (FC) and the end user's intention to adopt smart-government services in the UAE (H4a). 
Other hypotheses of the study prompted investigation of the impact of age as a moderator of facilitating-condition that influences the use of smart-government services in the UAE. The MGA results showed no significant differences between younger and older users. Both groups demonstrated a significant impact of FC on UB, with an insignificant MGA $p$ value $>0.1$ and $<0.90$. One possible explanation for this result is demographic information confirming that $32 \%$ of study participants were 30 years old or younger, making the other $68 \%$ older. Although participants age ranges reflect average ages in the UAE, they fail to allow for significant differences between the groups. The similar findings were reported by Alshehri et al. (2013) and Khalil (2014). However, Ghalandari (2012) and Venkatesh et al. (2003) report contrary findings, identifying age as a significant factor influencing the facilitating conditions that promote the use of e-services, and this effect became stronger as the respondents became younger.

Internet experience had a significant effect on facilitating-condition influence on usage behavior for smart-government services (for less $\mathrm{m}$-internet experience, $\beta=0.28, p<0.1$ and for high $\mathrm{m}$-internet experience $\beta=0.21, \mathrm{p}<0.1$ ). Therefore, the multigroup analysis did not show a significant difference between the two groups $(p>0.1$ and $<0.90)$. An explanation for these findings may be due to the majority of the study participants who are employees. Although the descriptive statistics showed that $46 \%$ of the study respondents had more than 5 years of m-internet experience and $54 \%$ had less than 5 years, their Internet background and educational level were close, so that a significant difference between the two groups did not appear. Furthermore, the similar findings were reported by Park et al. (2007) and Khalil, (2014), which contradict those of AlAwadhi and Morris (2008) and Alshehri et al. (2013), who reported that Internet experience is an important moderating factor influencing the facilitating conditions in favor of adoption of smart government service.

\section{Trust In Technology}

The researchers anticipated that trust in technology would be an important factor in the context of the UAE. It is recognized as a key factor in the adoption of mobile-based services (Pavlou, 2003). In this regard, Carter and Bélanger (2005) highlight the need for end-users to have confidence in the enabling technologies. This hypothesis suggests that users' trust in technology (integrated with trust in the Internet) will significantly affect their intentions to adopt smart-government services in the UAE. The statistical results show that this hypothesis is not supported $(\beta=0.07$ and $p \geq 0.1$ ). Privacy is a critical factor in determining acceptance of smart-government services (Alomari et al., 2012; Hussein et al., 2011).

Privacy was also supported as a critical factor in e-government services research in a study by Al-Gaith et al. (2010). This finding could be explained by lower respondent ratings due to the high level of smart-device penetration in the UAE, whose residents have a solid background in using these devices, making them confident in dealing with government services. Furthermore, most of the study's respondents are employees with a similar educational level and comparable knowledge of smartphone devices. Therefore, trust in technology was rated lower due to the fact that end-users have not had to face a security or privacy issue when using smart-government services in the UAE.

This research does suggest that the factors of gender, age, and m-internet experience moderate the influence of trust in technology on the acceptance of smart-government services in the UAE. The statistical results (see Table 10) of the Multigroup analysis revealed an insignificant impact of gender and age on trust of technology as an influence on adoption of smart-government services in UAE. One explanation might be that respondents to the study have a quite similar level of background in using these devices, or that they trusted the government infrastructure and systems. As a result, this construct was not highly rated, failing to demonstrate significant differences, especially when considering age and gender dimensions.

Alsaif (2014) found that the more Internet experience users have, the more trust they have in the Internet, resulting in an increase of use of e-government services. This study shows that respondents with a lower level of experience are influenced by trust in technology in their intention 
to use smart-government services (MGA $p<0.1$ ). The similar findings suggest that when there was less Internet and technology experience, the risk concerns regarding technology adoption increased (George, 2002). These findings might be explained by the fact that the unwillingness or hesitancy on the part of respondents to use smart-government systems was reduced when their trust in using mobile technologies and their experience with the Internet is increased. In the UAE, the government is encouraged to demonstrate how secure the technology is to get more user adoption, especially from those who have less m-internet experience.

\section{Trust In Government}

The statistical results reveal a significant positive impact by trust in government on end users' behavioral intention to use smart-government services in the context of the UAE. Therefore, the hypothesis is supported $(\beta=0.25$ and $p<0.1)$. Similarly, the previous studies in the fields of e-government service adoption support these findings (Al Thunibat \& Sahari, 2011; Alomari et al., 2012; Hussein et al., 2011). These researchers reported a direct significant impact of trust in government on the intention to use electronic government services. Furthermore, a study by Abu-Shanab (2014) highlighted the importance of trust in government in e-government adoption.

These findings showed that trust in government is an important factor influencing the intention to use smart-government services, particularly when users are required to provide their confidential personal information, such as Emirates ID, credit card, bank account, or contact details. Indeed, the end-users view government as Big Brother (Al Thunibat \& Sahari, 2011). Various researchers (e.g., Carter \& Bélanger, 2005) have highlighted the importance of confidence in the government for the adoption of e-services. Rehman et al. (2012) pointed out that a lower level of trust in government is one of the critical factors in the failure of $\mathrm{m}$-government projects. This highlights the importance of considering the sociocultural moderation factors' impact on the trust in government construct, which is further explained below.

There is scanty evidence in the literature of empirical tests of moderation, especially in the $\mathrm{m}$-government domain. This study suggests that the factors of gender, age, and m-internet experience would affect trust in government as an influence on users' intentions to accept and use smartgovernment services. Regarding the moderation effect of gender, the multigroup analysis (MGA) done with the SmartPLS application (see Table 10) revealed that men $(\beta=0.42$ and $p<0.1)$ are more influenced by trust of government in adopting smart government than women $(\beta=0.17$ and $p<$ 0.1 ) with the MGA $p$-value $\leq 0.1$ indicating significance. Although both groups (males and females) showed the significant influence of trust in government to provide safe, secure, and reliable smart services, these findings could be explained by the culture of the UAE society where men are more responsible for performing government transactions, and women often rely on men to finalize them. Men may tend to adopt smart-government services (influenced by trust in government) as they will have more responsibility for dealing with the government services using these smart applications.

The study showed that both younger and older respondents are influenced by trust in government: $(\beta=0.24$ and $p<0.5)$ and $(\beta=0.23$ and $p<0.1)$. The MGA did not show a significant difference between these two groups. One possible explanation is that, as seen in the descriptive statistics, the younger group consists of only $32 \%$ of the total number of respondents; thus a significant difference may have failed to appear, so the hypothesis is not supported. Furthermore, the regression analysis showed that users with more m-internet experience $(\beta=0.46$ and $p<0.1)$ are more influenced by trust in government in their intention to use smart-government services. For users with less m-internet experience $(\beta=0.12$ and $p>0.1)$, the impact of trust in government was insignificant, and the MGA showed a significant difference ( $p$-value $\leq 0.1$ ), and thus the hypothesis is supported. This might be explained by the fact that less experienced users have dealt much less with the Internet in accessing government services, doing online transactions, searching for information, and using government mobile apps. In addition, they may use their smartphones primarily for social purposes. 
More experience in using the Internet contributes to increased trust in the capabilities of government to provide smart services, so that those with more experience are more likely to use the smartgovernment services.

\section{IMPLICATIONS FOR THEORY AND PRACTICE}

The paper helps to understand the key issues surrounding the mobile devices adoption in government services. Our findings have several theoretical and practical implications. This article makes several contributions to the literature. Giving the rising interest in smart-government services, this paper focuses on the end-users acceptance which seems to be a significant gap in our knowledge. This paper contribute to the conceptualisation of the intention to use smart government services, and develops a conceptual framework relating to its adoption in the UAE. This article expands the traditional discussion of Venkatesh et al.'s (2003) model, by incorporating trust in technology and trust in government that act as facilitator in the intention to use smart-government services.

We propose and test an integrated framework in which performance expectancy, effort expectancy, social influence, and facilitating condition, trust in technology, and trust in government have direct impact on the intention to use mobile technologies in smart government services. Moreover, this paper brings them together to explain the moderation effect of gender, age, and experience of using mobile devices on their linkage, and quantifies the relationship. For example, this study proves that smartphone-payment experience is a critical moderator that affects the adoption of the smartgovernment services.

This study provides government officials and practitioners with an understanding of the factors that should be given emphasis in enhancing the intention to use smart-government services. The article also helps practitioners to understand key constructs in various forms that are issues in causing the variation in the intention to use smart government services. The proposed model provides the government agencies with a list of determinants of smart-government services acceptance by its citizens in a profile-based analysis of sociocultural values. The findings of the study will help the government officials and policy makers in formulating strategies to encourage the adoption and acceptance of smart-government services by the UAE end-users. Moreover, this findings derived from the empirical analysis can motivate the society to expedite and increase smart-government services adoption.

\section{LIMITATIONS AND FUTURE RESEARCH DIRECTIONS}

This study should be assessed in light of its limitations. First, since the data were drawn only from a single country (i.e., the UAE), the findings may not be generalizable to other contexts. Future study can test the research model in other contexts (e.g., developing countries). Second, our research did not cover comprehensively all the factors that influence the end-users' intension of using the smartgovernment services. There are other important variables, e.g., services quality, perceived usefulness, perceived risk, cost of service, awareness, and perceived compatibility, which are being taken into account in the future work. Thirdly, cross-sectional data were used in this study. Future research may use longitudinal data to test causality between the key determinants. Fourthly, only the views of end-users based in the UAE were considered in the subjective instruments used to discuss the factors that influence the end-users' intension of using the smart-government services. The views of smart-government service providers may be different. To ensure robust results, these views should be considered in a future study. 


\section{CONCLUSION}

In recent years, the smart technologies such as mobile Internet technology play a significant role in the management of operations of organisations in both public and private sectors. The acceptance of smart government services is treated as a function of user involvement in smart government service applications. This article identifies the factors that affect the adoption of smart government services, and develops a conceptual framework. This study assessed the proposed model empirically to shed some light on the links between performance expectancy, effort expectancy, social influence, facilitating condition, trust in technology, and trust in government, along with the moderation effects of gender, age, and experience of the end-users on this linkage. The policy makers and practitioners need to use an appropriate construct to ensure the effective operation and use of smart-government services. Hence, the paper helps them to understand key constructs in various forms that are issues in causing the variation in the intention to use smart government services. Policy makers and practitioners can give emphasis on these factors to enhance the adoption of smart-government services. The current research advances academic research on the topic and opens doors for additional research aimed at better understanding of the adoption of smart government services. 


\section{REFERENCES}

Abdelghaffar, H., \& Magdy, Y. (2012). The adoption of mobile government services in developing countries: The case of Egypt. International Journal of Information, 2(4), 333-341.

Abdou, D., \& Jasimuddin, S. M. (2020). The Use of the UTAUT Model in the Adoption of E-Learning Technologies - An Empirical Study in France based Banks. Journal of Global Information Management, 28(4), 38-51. doi:10.4018/JGIM.2020100103

Abu-Shanab, E. (2014). Antecedents of trust in e-government services: An empirical test in Jordan. Transforming Government: People, Process and Policy, 8(4), 480-499.

Ahmad, M. O., Markkula, J., \& Oivo, M. (2013). Factors affecting e-government adoption in Pakistan: A citizen's perspective. Transforming Government: People, Process and Policy, 7(2), 225-239.

Al-Gahtani, S. S., Hubona, G. S., \& Wang, J. (2007). Information technology (IT) in Saudi Arabia: Culture and the acceptance and use of IT. Information \& Management, 44(8), 681-691. doi:10.1016/j.im.2007.09.002

Al-Khouri, A.M. (2012). eGovernment strategies the case of the United Arab Emirates (UAE). European Journal of ePractice, (17), 126-150.

Al-Shafi, S., \& Weerakkody, V. (2010). Factors affecting e-government adoption in the state of Qatar. Proceedings of European and Mediterranean Conference on Information Systems.

Al Thunibat, A., \& Sahari, N. (2011). Modelling the factors that influence mobile government services acceptance. African Journal of Business Management, 5(34), 13030-13043.

Al Zaabi, M. (2019). Driving an ambitious vision with excellence the UAE Government excellence model. International Journal of Excellence in Government, 1(1), 8-14. doi:10.1108/IJEG-02-2019-0004

AlAwadhi, S., \& Morris, A. (2008 January). The use of the UTAUT model in the adoption of e-government services in Kuwait. In Hawaii International Conference on System Sciences, Proceedings of the 41st Annual (p. 219). IEEE. doi:10.1109/HICSS.2008.452

Almuraqab, N., \& Jasimuddin, S. M. (2017). Exploring factors that influence end-users' adoption of smart government services: A conceptual framework in the UAE. The Electronic Journal of Information Systems Evaluation, 20(1), 11-23.

Almuraqab, N., Jasimuddin, S. M., \& Mansoor, W. (2017). Mobile government (mGovernment) Adoption factors in the UAE: A conceptual Framework based on UTAUT. International Journal of Engineering Technology. Management and Applied Sciences, 5(3), 14-19.

Almuraqab, N. A. S. (2017). M-Government adoption factors in the UAE: A partial least squares approach. International Journal of Business and Information, 11(4), 404-431.

Almuraqab, N. S., \& Jasimuddin, S. M. (2016, May). A literature survey of m-government services adoption: Lessons for a smart city success. In GCC Smart government \& Smart cities conference, At Dubai (Vol. 22, pp. 1-12). UAE.

Alomari, M., Woods, P., \& Sandhu, K. (2012). Predictors for e-government adoption in Jordan: Deployment of an empirical evaluation based on a citizen-centric approach. Information Technology \& People, 25(2), 207-234. doi: $10.1108 / 09593841211232712$

Alsaif, M. (2014). Factors affecting citizens' adoption of e-government moderated by socio-cultural values in Saudi Arabia (Doctoral dissertation). University of Birmingham.

Alshehri, M., Drew, S., \& AlGhamdi, R. (2013). Analysis of citizens' acceptance for e-government services: Applying the UTAUT model. arXiv preprint arXiv:1304.3157.

Carter, L. (2008). E-government diffusion: A comparison of adoption constructs. Transforming Government: People. Process and Policy, 2(3), 147-161.

Carter, L., \& Bélanger, F. (2005). The utilization of e-government services: Citizen trust, innovation and acceptance factors. Information Systems Journal, 15(1), 5-25. doi:10.1111/j.1365-2575.2005.00183.x 
Carter, L., \& Weerakkody, V. (2008). E-government adoption: A cultural comparison. Information Systems Frontiers, 10(4), 473-482. doi:10.1007/s10796-008-9103-6

Dahi, M., \& Ezziane, Z. (2015). Measuring e-government adoption in Abu Dhabi with technology acceptance model (TAM). International Journal of Electronic Governance, 7(3), 206-231. doi:10.1504/IJEG.2015.071564

Debusmann, J. (2015). 96.3\% marks for m-government initiative in 41 entities. Khaleej Times. Available at https://www.khaleejtimes.com/nation/government/96.3-marks-for-m-government-initiative-in-41-entities

Fornell, C., \& Larcker, D. F. (1981). Structural equation models with unobservable variables and measurement error: Algebra and statistics. JMR, Journal of Marketing Research, 18(3), 382-388. doi:10.1177/002224378101800313

Gefen, D., Straub, D., \& Boudreau, M. C. (2000). Structural equation modeling and regression: Guidelines for research practice. Communications of the Association for Information Systems, 4(1), 7. doi:10.17705/1CAIS.00407

George, J. F. (2002). Influences on the intent to make Internet purchases. Internet Research, 12(2), 165-180. doi:10.1108/10662240210422521

Ghalandari, K. (2012). The effect of performance expectancy, effort expectancy, social influence and facilitating conditions on acceptance of e-banking services in Iran: The moderating role of age and gender. Middle East Journal of Scientific Research, 12(6), 801-807.

Gilbert, D., Balestrini, P., \& Littleboy, D. (2004). Barriers and benefits in the adoption of e-government. International Journal of Public Sector Management, 17(4), 286-301. doi:10.1108/09513550410539794

Hair, J. F., Black, W. C., Babin, B. J., Anderson, R. E., \& Tatham, R. L. (2006). Multivariate Data Analysis. Pearson Prentice Hall.

Hussein, R., Mohamed, N., Rahman Ahlan, A., \& Mahmud, M. (2011). E-government application: An integrated model on G2C adoption of online tax. Transforming Government: People, Process and Policy, 5(3), $225-248$.

Islam, Z., Jasimuddin, S. M., \& Hasan, I. (2017). The role of technology and socialization in linking organizational context and knowledge conversion: The case of Malaysian service organizations. International Journal of Information Management, 37(7), 497-503. doi:10.1016/j.ijinfomgt.2017.06.001

Jasimuddin, S. M., Li, J., \& Perdikis, N. (2015). Linkage between Geographic Space and Knowledge Transfer at MNCs: A Structural Equation Approach. The Annals of Regional Science, 54(3), 769-795. doi:10.1007/ s00168-015-0684-y

Jasimuddin, S. M., Li, J., \& Perdikis, N. (2019). An empirical study of the role of knowledge characteristics and tools on knowledge transfer in China-based Multinationals. Journal of Global Information Management, 27(1), 165-195.

Jasimuddin, S. M., Mishra, N., \& Almuraqab, N. (2017). Modelling the factors that influence the acceptance of digital technologies in e-government services: A PLS-SEM Approach. Production Planning and Control, 28(16), 1307-1317. doi:10.1080/09537287.2017.1375144

Khalil, O. E. (2014). The adoption of the traffic violation e-payment system (TVEPS) of Kuwait. Electronic Journal of E-Government, 12(1), 3.

Khan, M. S., Woo, M., Nam, K., \& Chathoth, P. K. (2017). Smart City and Smart Tourism: A Case of Dubai. Sustainability, 9(12), 2279. doi:10.3390/su9122279

Kurfalı, M., Arifoğlu, A., Tokdemir, G., \& Paçin, Y. (2017). Adoption of e-government services in Turkey. Computers in Human Behavior, 66, 168-178. doi:10.1016/j.chb.2016.09.041

Liu, Y., Li, H., Kostakos, V., Goncalves, J., Hosio, S., \& Hu, F. (2014). An empirical investigation of mobile government adoption in rural China: A case study in Zhejiang Province. Government Information Quarterly, 31(3), 432-442. doi:10.1016/j.giq.2014.02.008

Morris, M. G., \& Venkatesh, V. (2000). Age differences in technology adoption decisions: Implications for a changing work force. Personnel Psychology, 53(2), 375-403. doi:10.1111/j.1744-6570.2000.tb00206.x

O’Dea, S. (2020). Smartphone users worldwide 2016-2021. https://www.statista.com/statistics/330695/numberof-smartphone-users-worldwide/ 
Park, J., Yang, S., \& Lehto, X. (2007). Adoption of mobile technologies for Chinese consumers. Journal of Electronic Commerce Research, 8(3), 196-206.

Pavlou, P. A. (2003). Consumer acceptance of electronic commerce: Integrating trust and risk with the technology acceptance model. International Journal of Electronic Commerce, 7(3), 101-134. doi:10.1080/10864415.200 3.11044275

Rehman, M., Esichaikul, V., \& Kamal, M. (2012). Factors influencing e-government adoption in Pakistan. Transforming Government: People. Process and Policy, 6(3), 258-282.

Sabraz Nawaz, S., \& Thelijjagoda, S. (2015). Sri Lankan end-users' use behaviour towards e-government services. European Journal of Business and Management, 7(8), 219-231.

Sang, S., Lee, J. D., \& Lee, J. (2010). E-government adoption in Cambodia: A partial least squares approach. Transforming Government: People. Process and Policy, 4(2), 138-157.

Shareef, M. A., Archer, N., \& Dwivedi, Y. K. (2012). Examining adoption behavior of mobile government. Journal of Computer Information Systems, 53(2), 39-49.

Sperber, A. D., Devellis, R. F., \& Boehlecke, B. (1994). Cross-cultural translation. Journal of Cross-Cultural Psychology, 25(4), 501-524. doi:10.1177/0022022194254006

Suki, N. M., \& Ramayah, T. (2010). User acceptance of the e-government services in Malaysia: Structural equation modelling approach. Interdisciplinary Journal of Information, Knowledge, and Management, 5(1), 395-413.

Tarhini, A., El-Masri, M., Ali, M., \& Serrano, A. (2016). Extending the UTAUT model to understand the customers' acceptance and use of internet banking in Lebanon: A structural equation modeling approach. Information Technology \& People, 29(4), 830-849.

Trocchia, P. J., \& Janda, S. (2000). A phenomenological investigation of Internet usage among older individuals. Journal of Consumer Marketing, 17, 605-616.

Venkatesh, V., Morris, M. G., Davis, G. B., \& Davis, F. D. (2003). User acceptance of information technology: Toward a unified view. Management Information Systems Quarterly, •••, 425-478.

World Bank. (2015). E-Government brief. Available at https://www.worldbank.org/en/topic/ict/brief/e-government 


\section{APPENDIX}

\section{Table 11. The measurement instrument}

\begin{tabular}{|c|c|c|}
\hline Construct & Questions & Reference \\
\hline \multirow[t]{4}{*}{$\begin{array}{l}\text { Performance } \\
\text { expectancy }\end{array}$} & $\begin{array}{l}\text { Using smart-government services enables me to accomplish my public-sector } \\
\text { needs more quickly. }\end{array}$ & \multirow{4}{*}{$\begin{array}{l}\text { (Venkatesh et al., 2003; AlAwadhi } \\
\text { and Morris, 2008; Al-Hujran and } \\
\text { Megdadi, 2013; Khalil, 2014) }\end{array}$} \\
\hline & $\begin{array}{l}\text { Using smart-government services makes it easier to accomplish my public- } \\
\text { sector needs. }\end{array}$ & \\
\hline & I find smart-government services useful in my life. & \\
\hline & $\begin{array}{l}\text { Using smart-government services increases my effectiveness (e.g. find } \\
\text { information about services within the shortest time frame) }\end{array}$ & \\
\hline \multirow[t]{4}{*}{ Effort expectancy } & Learning how to use smart-government services is easy for me. & \multirow{4}{*}{$\begin{array}{l}\text { (Venkatesh et al., 2003; AlAwadhi } \\
\text { and Morris, 2008; Al-Hujran and } \\
\text { Megdadi, 2013; Khalil, 2014) }\end{array}$} \\
\hline & My interaction with smart-government services is clear and understandable. & \\
\hline & I find smart-government services easy to use. & \\
\hline & It is easy for me to become skillful at using smart-government services. & \\
\hline \multirow[t]{3}{*}{ Social influence } & People who are important to me think that I should use smart-government & \multirow{3}{*}{$\begin{array}{l}\text { (Venkatesh et al., 2003; AlAwadhi } \\
\text { and Morris, 2008; Al-Hujran and } \\
\text { Megdadi, 2013; Khalil, 2014) }\end{array}$} \\
\hline & People who influence my behavior think that I should use smart-government & \\
\hline & $\begin{array}{l}\text { People who are important to me would find using smart-government to be } \\
\text { beneficial }\end{array}$ & \\
\hline \multirow[t]{6}{*}{ Facilitating conditions } & $\begin{array}{l}\text { I have the resources necessary to use smart-government services (e.g. internet } \\
\text { connection, smartphone) }\end{array}$ & \multirow{6}{*}{$\begin{array}{l}\text { (Venkatesh et al., 2003; AlAwadhi } \\
\text { and Morris, 2008; Al-Hujran and } \\
\text { Megdadi, 2013; Khalil, 2014) }\end{array}$} \\
\hline & I have the knowledge necessary to use smart-government services & \\
\hline & $\begin{array}{l}\text { I can get help from others when I have difficulties using smart-government } \\
\text { services }\end{array}$ & \\
\hline & Smart-government is compatible with technologies I use & \\
\hline & $\begin{array}{l}\text { Using smart-government services fits well with the way I like to deal with } \\
\text { government. }\end{array}$ & \\
\hline & Using smart-government services fits my lifestyle & \\
\hline \multirow[t]{5}{*}{ Trust of technology } & I trust the security of the internet & $\begin{array}{l}\text { (Al Thunibat and Sahari., 2011; Abu- } \\
\text { Shanab, 2014; Almuraqab, 2017) }\end{array}$ \\
\hline & Technical infrastructure is sufficient in protecting my information & $\begin{array}{l}\text { (Al Thunibat and Sahari., 2011; Abu- } \\
\text { Shanab, 2014; Almuraqab, 2017) }\end{array}$ \\
\hline & In general, the internet is trusted nowadays & $\begin{array}{l}\text { (Al Thunibat and Sahari., 2011; Abu- } \\
\text { Shanab, 2014; Almuraqab, 2017) }\end{array}$ \\
\hline & I trust smartphones when I use them in smart-government transactions & Added by author \\
\hline & I trust the mobile apps of smart-government & Added by author \\
\hline \multirow[t]{3}{*}{ Trust of government } & I trust public departments and agencies & $\begin{array}{l}\text { (Al Thunibat and Sahari., 2011; Abu- } \\
\text { Shanab, 2014; Almuraqab, 2017) }\end{array}$ \\
\hline & I trust government's capability to provide safe smart services & $\begin{array}{l}\text { (Al Thunibat and Sahari., 2011; Abu- } \\
\text { Shanab, 2014; Almuraqab, 2017) }\end{array}$ \\
\hline & I trust that end-users' interests are the government's first priority & $\begin{array}{l}\text { (Al Thunibat and Sahari., 2011; Abu- } \\
\text { Shanab, 2014; Almuraqab, 2017) }\end{array}$ \\
\hline \multirow[t]{3}{*}{ Behavioral intention } & I intend to use smart-government services & \multirow{3}{*}{$\begin{array}{l}\text { (Venkatesh et al., 2003; AlAwadhi } \\
\text { and Morris, 2008; Al-Hujran and } \\
\text { Megdadi, 2013; Khalil, 2014) }\end{array}$} \\
\hline & I predict that I will use smart-government services & \\
\hline & I plan to use smart-government services & \\
\hline \multirow{3}{*}{$\begin{array}{l}\text { Use Behavior (Actual } \\
\text { use) }\end{array}$} & I have used smart-government mobile apps to access government services & \multirow{3}{*}{$\begin{array}{l}\text { Sabraz and Thelijjagoda, 2015; Khalil, } \\
\text { 2014) }\end{array}$} \\
\hline & I have used smart-government mobile apps to pay for government services & \\
\hline & $\begin{array}{l}\text { I have used smart-government mobile apps to enquire or follow up government } \\
\text { services }\end{array}$ & \\
\hline
\end{tabular}


Nasser A. Saif Almuraqab is an Assistant Professor, Chief Operating Officer, and director of the IT services department at University of Dubai since October 2013. He is doing PhD in business administration, (MIS) from Dubai Business School, University of Dubai. He has an MBA from Abu Dhabi University and a bachelor's degree in MIS from the UAE University. He has more than 12 years of experience in IT and project management, and consultancy. He has published various articles in top journals (e.g., Production Planning and Control). His research interests in MIS, and Business and Information fields, and areas like $m$-government, $m$-services, $m$-learning, and technology acceptance.

Sajjad M. Jasimuddin is Professor at the Kedge Business School, France since July 2012. Previously, he taught at Aberystwyth University, Southampton University, King Abdulaziz University, and University of Dhaka. He received MPhil from Judge Business School at Cambridge University (Trinity College), and PhD from Southampton University. He authors 13 chapters and 110 articles, appear in European Journal of Operational Research, Information Systems Journal, Annals of Regional Science, Thunderbird International Business Journal, European Management Journal, Information Systems Management, Journal of Operational Research Society, Industrial Management \& Data Systems, Management Decision, Journal of Business \& Industrial Marketing, Global Business and Organizational Excellence, International Journal of Organizational Analysis, IJIM, Journal of Management Analytics, Journal of Knowledge Management, JGIM, JIKM, K\&PM, IJTHI, EJISE, IRMJ, VINE and KMR\&P. Recently, he published a book, Knowledge Management: An Interdisciplinary Perspective (World Scientific, 2012). His research interests are in knowledge management, international business, information management, and strategic management.

Wathiq Mansoor is a Professor and Dean of College of Engineering and IT at University of Dubai since October 2013. He did PhD in Engineering and IT from Warwick University. His research interests in Engineering and IT, m-learning, and technology acceptance. 